\title{
Jurisdictional Immunities of Intergovernmental Organizations
}

In 1945, Congress enacted the International Organizations Immunities Act $^{1}$ (the IOIA), granting certain intergovernmental organizations ${ }^{2}$ (IGOs) "the same immunity from suit and every form of judicial process as is enjoyed by foreign governments";,3 at that time, foreign governments were absolutely immune from the jurisdiction of both state and federal courts in the United States. ${ }^{4}$ Recently, however, Congress passed the Foreign Sovereign Immunities Act of $1976^{5}$ (the FSIA), which severely curtailed that immunity ${ }^{6}$ and thus raised the question whether the FSIA restricted the international immunities conferred by the IOIA. The only court to address this problem, the Circuit Court for the District of Columbia, has left it unresolved.?

This Note considers both whether the FSIA supersedes the IOIA and

1. 8 U.S.C. $\S 215,22$ U.S.C. $\S \S 288-288 f, 26$ U.S.C. $\$ \S 892,3306(c)(16), 3401(a)(5), 4253(c)$, 7701 (a)(18), 42 U.S.C. $\S 409$ (1976).

2. Referred to as international organizations by the IOIA, intergovernmental organizations are "public international organizations," or "those [organizations] which are composed of governments as members," H.R. REP. NO. 1203, 79th Cong., 1st Sess. 1, reprinted in 1945 U.S. CONG. SERV. 946, 946 [hereinafter cited as 1945 HOUSE REPORT; all page citations are to reprint]. This Note considers only IGOs meeting the IOIA's requirements for immunity: those in which the United States "participates" and which the President has designated as "entitled to enjoy" the benefits provided by that Act, see 22 U.S.C. $\$ 288$ (1976).

3. 22 U.S.C. $\S 288 \mathrm{a}(\mathrm{b})$. The immunities pertaining to IGOs are known as international immunities.

4. See 1945 HOUSE REPORT, supra note 2, at 948; S. REP. NO. 861, 79th Cong., 1st Sess. 4 (1945) [hereinafter cited as 1945 SENATE REPORT]; see also infra pp. 1174-1176 (discussing absolute foreign sovereign immunity before 1945).

5. 28 U.S.C. $\$ \S 1330,1332(a)(2)-(4), 1391(f), 1441(3), 1602-1611$ (1976).

6. Under the FSIA, "the immunity of a foreign state is 'restricted' to suits involving a foreign state's public acts (jure imperii) and does not extend to suits based on its commercial or private acts (jure gestionis)." H.R. REP. NO. 94-1487, 94th Cong. 2d Sess. 7, reprinted in 1976 U.S. CODE CONG. \& AD. NEWS 6604, 6605 [hereinafter cited as 1976 HouSE REPORT]. Commercial acts include, for example, activities "customarily carried on for profit" and the making of any contract "which might be made by a private person." Id. at 16 . Thus, a state should be immune with regard to actions that only a state can perform, but not with regard to actions that a private person, as well as a state, could perform. Kahale \& Vega, Immunity and Jurisdiction: Toward a Uniform Body of Law in Actions Against Foreign States, 18 ColuM. J. TRANSNAT'L L. 211, 212 (1979).

7. See Broadbent v. OAS, 628 F.2d 27, 32-33 (D.C. Cir. 1980); accord, Tuck v. Pan Am. Health Org., 668 F.2d 547, 550 (D.C. Cir. 1981). Plaintiffs alleged breach of employment contract by improper discharge and award of inadequate compensation therefor by internal tribunal. Id. at 28-29. The court held that, on those facts, "[o]n either theory of immunity-absolute or restrictive-an immunity exists sufficient to shield the organization from lawsuit . . ." Id. at 32-33; see also Tuck, 668 F.2d at 550 (similar holding in suit by attorney to employees of organization). 
to what extent IGOs should now enjoy jurisdictional immunity under the IOIA. It also considers what recourse a plaintiff should have in the event an IGO defendant is immune.

\section{The Effect of the FSIA on the IOIA}

Writing for the court in Broadbent v. $O A S,{ }^{8}$ the late Judge Leventhal first discussed, but found it unnecessary to decide, whether the FSIA restricted the immunities conferred by the IOIA by operation of law. ${ }^{9}$ This Note attempts to demonstrate that there was no such effect.

\section{A. The IOIA: History and Purpose}

Close analysis of the IOIA establishes that granting IGOs "the same" judicial immunity as that of foreign sovereigns ${ }^{10}$ was intended to confer independent "immunities of a governmental nature," sovereign immunity as such. ${ }^{12}$ The international immunities in question were completely distinct from foreign sovereign immunities, being designed specifically to "enabl[e] this country to fulfill its commitments in connection with its membership in international organizations . . .."13

Before the enactment of the IOIA, American law made no provision for jurisdictional immunity for either an IGO or its personnel, even though IGOs were composed of immune foreign or domestic governments. ${ }^{14}$ Since the United States did, however, recognize the legal capacity or personality of IGOs, this lack of immunity meant that the organization, as well as its personnel, was vulnerable to suit on the same basis as a private party..$^{15}$ With the increasing participation of the United States in IGOs after World War II, this anomaly generated increasing friction. ${ }^{16}$ But it was

8. 628 F.2d 27 (D.C. Cir. 1980).

9. Id. at $30-33$.

10. 22 U.S.C. $\$ 288 \mathrm{a}$ (b) (1976) (quoted supra p. 1167).

11. 1945 HOUSE REPORT, supra note 2, at 946; 1945 SENATE REPORT, supra note 4, at 1.

12. Cf. Fedder, The Functional Basis of International Privileges and Immunities: $A$ New Concept in International Law and Organization, 9 AM. U.L. REV. 60, 64 (1960) (IOIA reference to foreign sovereign immunity "can only be explained as one of convenience").

13. 1945 HOUSE REPORT, supra note 2 , at 951 ; 1945 SENATE REPORT, supra note 4 , at 3.

14. See 1945 HOUSE REPORT, supra note 2, at 946-47; 1945 SENATE REPORT, supra note 4, at 2. For a sketch of the pre-1945 history of international immunities in general, see Kunz, Privileges and Immunities of International Organizations, 41 AM. J. INT'L L. 828, 828-36 (1947).

15. Preuss, The International Organizations Immunities Act, 40 AM.' J. INT'L L. 332, 333-34 (1946).

16. See id. This friction was due largely to the Treasury's demands for income and other taxes, id. at 334, which were resented as a local tax on international officials paid by funds contributed by foreign states, see id:; Letter from the Director General of the United Nations Relief and Rehabilitation Agency to the Secretary of State, in Sponsorship by the Department of State of Legislation Resulting in the International Organizations Immunities Act of 1945, [1945] 1 FOREIGN REL. U.S. 1557, 1557 (letters to and from Secretary of State re international immunities legislation) (hereinafter cited as IOIA Letters]. Similarly, the legislative history of the IOIA contains many allusions to tax matters, 
only with the formation of, and United States membership in, the United Nations that immunities legislation became "essential."17 Consequently, the discussion of immunities that then occurred may shed light on the question of the intended meaning of the IOIA's provisions.

The immunities bill was drafted and sponsored by the State Department. ${ }^{18}$ The Secretary of State had recently ${ }^{19}$ submitted to the President a report ${ }^{20}$ from the United States delegation to the San Francisco Conference on the United Nations Charter. ${ }^{21}$ This report concluded that Article 105, the Charter's immunities provision, ${ }^{22}$ required the United States as a member of the United Nations to enact appropriate legislation: ${ }^{23}$ almost certainly, the IOIA. ${ }^{24}$ The Act thus may be understood at least partly as the authoritative interpretation in United States law of Article 105's "necessary" immunities for the United Nations, ${ }^{25}$ applied to IGOs in general. ${ }^{26}$

1945 HOUSE REPORT, supra note 2, passim; 1945 SENATE REPORT, supra note 4, passim, including letters of consent from the Secretary of the Treasury and the Bureau of the Budget, 1945 HouSE REPORT, supra note 2, at 951-52. Cf. UNITED NATIONS, ANNUAL REPORT OF THE SECRETARY-GENERAL ON THE WORK OF THE ORGANIZATION 104-5, G.A.O.R., 10th Sess., Supp. No. 1, U.N. Doc. A/ 2911 (1955) (focusing on need for immunity from domestic taxation).

17. That probability, "and the practical certainty in any case that [the United Nations] would carry on certain activities in this country, make it essential to adopt this type of legislation promptly. The committee considers that the passage of this legislation is essential to implement our participation in this Organization." 1945 HOUSE REPORT, supra note 2, at 947; see generally IOIA Letters, supra note 16 .

18. Letter from Howard K. Smith, Director of the Bureau of the Budget, to the Secretary of State, Nov. 6, 1945, reprinted in 1945 HOUSE REPORT, supra note 2, at 951; IOIA Letters, supra note 16.

19. June 26, 1945. SAN FRANCISCo REPORT, infra note 20, at 9. The IOIA itself is dated December $29,1945.22$ U.S.C. $\$ 288$. The IOIA Letters, supra note 16 , demonstrate sustained effort after July 2.

20. U.S. DeP'T of State, Pub. No. 2349, Report to the President on the Results of the SAN FRANCISCO CONFERENCE (1945) [hereinafter cited as SAN FrANCISCO REPORT].

21. The Secretary himself had chaired that delegation. See id. at 28-29 (listing members of and principal advisors to United States delegation). The eminence of the delegation's members and advisors suggests both the importance of their task and that great weight attached to their conclusions and opinions.

22. "The Organization shall enjoy in the territory of each of its Members such privileges and immunities as are necessary for the fulfillment of its purposes." U.N. CHARTER art. 105, para. 1.

23. See SAN FRANCISCO REPORT, supra note 20, at 160.

24. In addition to the linkage suggested by common authorship and close time sequence, there are several striking similarities between the language and thinking of the SAN FRANCISCO REPORT, supra note 20, and the 1945 HOUSE, supra note 2, and SENATE REPORTS, supra note 4: for example, the references to the need mentioned earlier, see supra p. 1168 , to provide for international immunities, 1945 HOUSE REPORT, supra note 2, at 946-47; 1945 SENATE REPORT, supra note 4, at 2; SAN FRANCISCO REPORT, supra note 20 , at 158 , and the very characterization of those immunities in terms of those of foreign sovereigns, see supra p. 1168,14 ; infra p. 1171.

25. Thus, the IOIA may have been meant to obviate the need for the convention for which Article 105 provides, U.N. CHARTER art. 105, para. 3. Preuss, supra note 15, at $341-42$. If so, it is interesting that the United States acceded only in 1970 to the General Convention on the Privileges and Immunities of the United Nations, adopted by General Assembly Feb. 13, 1946, 21 U.S.T. 1418, T.I.A.S. No. 6900 (entered into force with respect to United States Apr. 29, 1970).

26. According to the legislative reports, each "committee understands that the provisions of the bill will satisfy in full the requirements of other international organizations conducting activities in the United States." 1945 HOUSE REPORT, supra note 2, at 947; 1945 SENATE REPORT, supra note 4, 
In addition, the IOIA itself was carefully structured to provide broad and flexible controls for the immunities it conferred, including Presidential power unilaterally to modify or revoke them; ${ }^{27}$ these controls were an integral and important part of the legislation. ${ }^{28}$ Although the 1945 House Report found that the immunities provisions themselves were "standard in the light of available precedents," 29 the Act was to apply only to those organizations "designated" by the President, not to IGOs generally. ${ }^{30}$ The Act, therefore, may also be understood as Congress' judgment that, apart from any requirements of the United Nations Charter, the immunities conferred were those appropriate to particular situations.

Because the IOIA immunities were thus tailored to specific organizations and situations, they are different from the immunities of foreign governments, which are laid down by general international or national law,

at 3. At least some of these "requirements," and of the United States "commitments" to IGOs to be satisfied by the IOIA, see supra p. 1168, would be the "[p]rovisions . . . made with respect to the problem of privileges and immunities . ..," 1945 HOUSE REPORT, supra note 2, at 947; 1945 SENATE REPORT, supra note 4, at 2, which remained unsatisfied prior to the enactment of the IOIA, see Letter from the Director General of UNRRA, supra note 16.

On this reading, the IOIA immunities would represent Congress' 1945 judgment that the "requirements" of other IGOs could be assimilated to those of the United Nations; the Act would then provide the immunities "necessary for the fulfillment of [the] purposes of" IGOs, U.N. CHARTER art. 105, para. 1 (quoted supra note 22); cf. infra p. 1181 (discussing theory of international immunities). Given the IOIA's emphasis on the United Nations, see supra p. 1169 , such a reading seems at least plausible.

27. See 22 U.S.C. $\$ 288$ (1976) (President authorized, first, in light of functions performed by IGO, to withhold, withdraw, condition, or limit enjoyment of immunities provided for; second, to revoke immunity of $I G O$ if, in his judgment, immunity abused, or for any other reason).

28. See 1945 HOUSE REPORT, supra note 2, at 948 ("Section [288] . . . is a basic provision to which the committee has given careful study. The committee believes that the interests of the United States are adequately protected by the restrictions which have been created.").

After the House Committee had considered the bill, the Justice Department, fearing that foreign nationals attached to the United Nations might commit espionage or disseminate hostile propaganda, proposed that the Executive be granted authority precisely to tailor the immunities conferred, see Letter from Attorney General Clark to Secretary of State Acheson, Oct. 2, 1945, in IOIA Letters, supra note 16, at 1563; the State Department revised the bill accordingly, see Letter from the Secretary of State to the Attorney General, Oct. 4, 1945, in id. at 1567. These revisions were specifically approved by the Senate Committee. 1945 SENATE REPORT, supra note 4 , at 2-3. This concern for the protection of United States interests, displayed throughout the consideration of the IOIA, suggests that Congress in fact intended to confer no greater immunity than was judged strictly necessary. $C f$. Letter from the Acting Secretary of State to the Attorney General, July 2, 1945, reprinted in IOIA Letters, supra note 16 , at 1560 (bill grants "less extensive privileges than . . . are accorded in various other countries" even before Senate amendments).

29. 1945 HOUSE REPORT, supra note 2, at 947; 1945 SENATE REPORT, supra note 4, at 3 . Congress thus judged that the IOI $\Lambda$ immunities were necessary to meet IGO requirements, either because other nations had also found such immunities necessary or because the United States could not confer narrower immunities without violating internationally accepted standards.

30. 22 U.S.C. $\$ 288$ (1976); cf. supra note 26 (drafters of IOIA had in mind specific IGOs and particular obligations).

31. Foreign sovereign immunities arise under international law, as modified by national law, see infra 1172-73 (discussing foreign sovereign immunity theory), whereas international immunities were derived from specific treaties and agreements. See, e.g., D. BOWETT, THE LAW OF INTERNATIONAL INSTITUTIONS 308-10 (1975). 
and are grounded on considerations such as reciprocity ${ }^{32}$ that do not apply to IGOs. ${ }^{33}$ Moreover, both the IOIA's legislative history and the San Francisco Report distinguish the immunities under consideration from those of foreign sovereigns. ${ }^{34}$ The structure and provisions of the IOIA also imply such a distinction. ${ }^{35}$

The IOIA's use of the word "same,"36 then, was intended to refer to, rather than to incorporate, established foreign sovereign immunity law. ${ }^{37}$

32. Reciprocity is the notion that if State $A$ does $P$ to or for State $B, B$ will do $P$ to or for $A$; or that $A$ will only do $P$ if $B$ agrees to reciprocate; or that $A$ need not do $P$ to or for $B$ if $A$ has no interest in whether $B$ reciprocates. The IOIA excludes direct reciprocity considerations from IGO immunities. 22 U.S.C. $\$ 288 \mathrm{f}$ (1976).

One author argues backwards from the FSIA that "this provision of the IOIA indicates that subsequent changes in United States law concerning foreign sovereign immunity were intended to have no bearing on the immunities granted by the IOIA." Note, Sovereign Immunity and International Organizations, 13 J. INT'L L. \& ECON. 675, 691 (1979). Because this argument seems to require, first, Congressional foreknowledge that those subsequent changes would be based on reciprocity considerations and, second, the counterfactual supposition that the changes actually were based entirely on such considerations, such a conclusion appears unwarranted.

33. Both committee reports explain that $\S 288 \mathrm{f}$ was intended

to make it clear that the privileges and immunities may be extended to international organizations even though such organizations are not in a position to accord similar treatment to the

United States; in substance the effect is to state that the reciprocity provisions which are con-

tained in certain laws providing for privileges and immunities to foreign governments would not be applicable in this situation.

1945 HOUSE REPORT, supra note 2, at 950; 1945 SENATE REPORT, supra note 4, at 6. Because reciprocity may be applied to foreign state nationals who are affiliated with IGOs, 22 U.S.C. $\S 288 f$ (1976), IGOs may incidentally be subject to reciprocity tactics aimed at their member states. Another example of the applicability of such indirect reciprocity is the comment of both legislative committees that

[t]he self-interest of this Government in legislation of this character is twofold since such legislation will not only protect the official character of public international organizations located in this country but it will also tend to strengthen the position of international organizations of which the United States is a member when they are located or carry on activities in other countries.

1945 HOUSE REPORT, supra note 2, at 947; 1945 SENATE REPORT, supra note 4, at 2.

34. See SAN FRANCISCO REPORT, supra note 20, at 159; see also 1945 HouSE REPORT, supra note 2, at 948-50 (immunities of IGO personnel said different in scope from immunities of foreign diplomats); 1945 SENATE REPORT, supra note 4, at 3-6 (same). If the personnel associated with an IGO are to be treated differently from the personnel associated with a foreign sovereign, an IGO and a forcign sovereign cannot possess precisely the "same" immunity. Cf. supra note 33 (discussing inapplicability of reciprocity considerations of foreign sovereign immunity).

Moreover, the "privileges to which international organizations and their officials will be entitled are somewhat more limited than those which are extended . . . to foreign governments." 1945 HOUSE REPORT, supra note 2, at 950-51; 1945 SENATE REPORT, supra note 4, at 3; see also SAN FRANCISCO REPORT, supra note 20, at 158 (diplomatic immunities described as settled and long-established, in contrast to emerging international immunities). This is not inconsistent, of course, with the committees' statements that the immunities bill puts IGOs "on the same basis as foreign governments" in many respects, 1945 HOUSE REPORT, supra note 2, at 948; 1945 SENATE REPORT, supra note 4, at 4, and that "the privileges and immunities provided ... are similar to those granted . . . to foreign governments and their officials," 1945 HOUSE REPORT, supra note 2, at 950; 1945 SENATE REPORT, supra note 4 , at 3.

35. Section $288 \mathrm{~d}(\mathrm{~b})$ describes the immunities of international personnel without linking those immunities to those of foreign states or of diplomatic representatives. Cf. supra note 34 (necessary implication of limitation on "sameness" of states and organizations).

36. Supra note 3.

37. But see O'Toole, Sovereign Immunity Redivivus: Suits Against International Organizations, 4 
International immunities in general were only intended to be "of a governmental character", 38 and jurisdictional immunity was merely to be "similar to" ${ }^{39}$ that of a foreign state, that is, absolute. ${ }^{40}$

\section{B. The FSIA: History and Purpose ${ }^{41}$}

The FSIA, on the other hand, "deals solely with sovereign immunity" in a commercial setting. ${ }^{42}$ The Act had two major objectives: to "codify the so-called 'restrictive' principle of sovereign immunity," the determination of sovereign immunity from the executive branch to the judicial branch." ${ }^{34}$ This Note argues that the Act was not intended to affect international immunities.

Chief Justice Marshall's opinion in The Schooner Exchange v. $M^{\prime}$ Faddon $^{45}$ is still the starting point for any discussion of the United States law of foreign sovereign immunity. He used the principles of comity, extraterritoriality, and reciprocity ${ }^{46}$ to imply the consent of a sovereign

SUFFOLK TRANSNAT'L. L.J. 1, 11-12 (1980) (Congress' overriding intent to treat IGOs and foreign sovereigns identically; adjusting scope of IOIA immunity to match FSIA necessary to achieve that intent). Professor O'Toole inquires little, however, into the IOIA's history. Cf. infra note 40 (that history refutes his assertion that IOIA does not define scope of immunity).

38. 1945 HOUSE REPORT, supra note 2, at 947; 1945 SENATE REPORT, supra note 4, at 2; sec supra p. 1168.

39. See 1945 HOUSE REPORT, supra note 2, at 950; 1945 SENATE REPORT, supra note 4, at 3.

40. See supra p. 1167. The IOIA's legislative history, then, defines the IOIA provisions, contrary to the supposition that the "Act . . . did not directly provide a definition of the scope of the immunity now to be extended to international organizations," O'Toole, supra note 37 , at 7.

The IOIA thus should be read as prescribing "the same [absolute] immunity from suit and cvery form of judicial process as is [now] enjoyed by foreign governments," cf. supra p. 1167 (quoting 22 U.S.C. $\$ 288 \mathrm{a}(\mathrm{b})$ ), in order clearly to state the intention of Congress. Professor O'Toole disagrees, arguing "that if Congress intended to ossify the immunities of international organizations it could easily have so declared by adding the words 'as of the date of this Act' to [\$288a(6)]." O'Toole, supra note 37 , at 11. Given, however, applicable principles of statutory construction, see infra pp. 1177-78, Congress had no need to do so to achieve such a purpose.

41. For an excellent analysis of the FSIA, see Weber, The Foreign Sovereign Immunities Act of 1976: Its Origin, Meaning and Effect, 3 Y $\Lambda$ LE STUD. WORLD PUB. ORD. 1 (1976); von Mehren, The Foreign Sovereign Immunities Act of 1976, 17 COLUM. J. TRANSNAT'L L. 33 (1978); and sources cited therein.

42. 1976 REPORT, supra note 6 , at 8 (contrasting sovereign with diplomatic immunity). The Act was not "intended to affect either diplomatic or consular immunity," id. at 12, which are the immunities attached to the representatives and embassies of foreign sovereigns and thus are concerned only with foreign states as such. The FSIA focuses, therefore, on only one aspect of foreign sovereign immunity: it is narrowly and "specifically addressed to foreign state defendants" acting commercially, id. at 7 .

43. Id. at 7. For a definition of that principle, see supra note 6; infra p. 1173.

44. 1976 REPORT, supra note 6 , at 7 . Congress feared that, because of diplomatic pressures, the State Department would not apply the restrictive theory in actual litigation, id., creating "considerable uncertainty" in that a "private party who deals with a foreign government entity cannot be certain that his legal dispute with a foreign state will not be decided on the basis of nonlegal considerations through the foreign government's intercession with the Department of State," id. at 9. That fear grew out of experience: the State Department often had been influenced by such considerations. Infra $p$. 1175 .

45. 11 U.S. (7 Cranch) 116 (1812).

46. The law of foreign sovereign immunity is based on these three principles. See, e.g., R. BLOCH 
to a waiver of jurisdiction ${ }^{47}$ over another sovereign amicably present within its boundaries. For well over a hundred years this holding was read to require complete immunity for foreign sovereigns from the jurisdiction of all courts $^{48}$ of the United States. ${ }^{49}$

But as sovereigns generally came to be regarded as subject to rather than above the law, ${ }^{50}$ and as states increasingly engaged in ordinary trade, $^{51}$ that absolute immunity came under attack ${ }^{52}$ and the principles sustaining it were eroded..$^{53}$ In spite of some incipient wavering,,$^{54}$ the Su-

\& J. LefeVRe, LA FONCTION PUbliQue INTERNATIONALE ET EUROPEenE 42 (1963); von Mehren, supra note 41 , at 35 \& n.9. Comity is the general practice of nations, see, e.g., 11 U.S. at 137; extraterritoriality deems certain persons or property physically located within a nation to be outside that nation's territory, see, e.g., id. at 136, 137; and reciprocity relies on the probability that actions will be reciprocated, see, e.g., id. at 136; see also supra note 32 (defining reciprocity). The "mutual benefit," or reciprocity, argument that Marshall employed, like the functional necessity of international immunities, see infra p. 1181; cf. supra pp. 1169-70 (IOIA provides only necessary immunitics), is the pragmatic justification for sovereign immunity. As such, it has come to be the dominant justification, see D. MiCHAELS, INTERNATIONAL PRIVILEGES AND IMMUNITIES 25 (1971), replacing the more normative principle of extraterritoriality or sovereign dignity that was determinative in the nineteenth century, see, e.g., 11 U.S. at 137.

47. See 11 U.S. 136, 143 (implication of consent); id. at 146 (sovereign may destroy implication); id. at 137 (waiver).

48. Although The Schooner Exchange was a federal case, see 11 U.S. at 117, so that the United States alone was the sovereign consenting to immunity, the state courts as well have perceived themselves to be bound by its pronouncements. See, e.g., Chemical Natural Resources v. Republic of Venez., 420 Pa. 134, 146-47, 215 A.2d 864, 869-77, cert. denied, 385 U.S. 822 (1966); see generally Annot., 25 A.L.R.3d 322, 329-30 \& n.4 (1969).

49. Not required by The Schooner Exchange, which provided only for rather narrow immunities, see 11 U.S. at 137, 138, 139, 145-46, this reading was adopted as a matter of policy by the Supreme Court. See Berizzi Bros. Co. v. Steamship Pesaro, 271 U.S. 562, 573-74 (1926).

50.

[T] he growing opposition to the jurisdictional immunities of foreign states has drawn its strength from factors aris[ing] to a large extent from the challenge to the prerogatives of the sovereign state which denies to the individual legal remedies for the vindication of his rights as against the state in the matter both of contract and of tort, and which asserts a privileged position for the state in the procedural sphere. That challenge has been largely successful in most states under the rule of law.

Lauterpacht, The Problem of Jurisdictional Immunities of Foreign States, 28 BRIT. Y.B. INT'L L. 220,220 (1951).

51. At present, governmental commercial activities account for approximately $30 \%$ of all international trading. W. REISMINN \& M. MCDOUGAL, INTERNATIONAL LAW IN CONTEMPORARY PERSPECTIVE (1981).

52. Courts and commentators have focused on the simple unfairness of states' claiming sovereign rights when acting like private persons. See, e.g., Trendtex Trading Corp. Ltd. v. Central Bank of Nigeria, [1977] 1 All E.R. 881, 891-92 (Denning, L.J.); Kuhn, The Extension of Sovereign Immunity to Government-Owned Commercial Operations, 39 AM. J. INT'L L. 772, 774-75 (1945). In such situations, a foreign sovereign may in effect be collecting an extraterritorial tax, since its trading activities may well be furthered by its exercise of its power-including its immunity-as a sovereign.

Chief Justice Marshall himself held that sovereigns need not always be treated as sovereigns. See, e.g., The Bank of the United States v. The Planters' Bank of Georgia, 22 U.S. (9 Wheat.) 904, 90708 (1824); The Schooner Exchange, 11 U.S. at 145 (dictum).

53. The fiction of extraterritoriality, which "asserts a privileged position for the state in the procedural sphere," Lauterpacht, supra note 50, at 220, was vulnerable on grounds of fairness, see supra note 52, and of irrationality: few reasons for governmental immunity can exist when a government chooses to operate as a private trader subject to commercial conditions rather than to exercise the authority peculiar to sovereigns. The extraterritoriality theory can be said largely to have been re- 
preme Court nevertheless continued to hold to the absolute theory. ${ }^{55}$ But just before enactment of the IOIA, Ex parte Republic of Peru ${ }^{56}$ and Republic of Mexico v. Hoffman ${ }^{57}$ authoritatively transferred primary responsibility for determining immunity in particular cases and for formulating policies for making those determinations to the State Department. ${ }^{\text {s8 }}$ Because, in the absence of a specific suggestion from the State Department, courts were still to apply the absolute theory as being the established policy of that Department, ${ }^{59}$ and because Ex parte Peru and Hoff-

placed, as in domestic jurisdictional law, see International Shoe Co. v. Washington, 326 U.S. 310 (1945), by a criterion of (fundamental) fairness. See, e.g., 1976 REPORT, supra note 6, at 6-7; Letter from Jack B. Tate, Acting Legal Adviser to the Dep't of State, to Philip B. Perlman, Acting Att'y Gen., May 19, 1952, 26 DEP'T ST. BULL. 984, 985 (1952) [hereinafter cited as Tate Letter]; infra notes $62,73$.

In addition, the principles of comity and reciprocity both favored a change in practice as the behavior of other countries changed. See, e.g., the Tate Letter, supra, at 985 (justifying such change in United States practice partly by finding "little support" around world "for continued full acceptance of the absolute theory of sovereign immunity," and that "long established policy" of United States of not claiming immunity in certain areas "most inconsistent" with "granting of sovereign immunity to foreign governments").

54. Compare Companía Española v. The Navemar, 303 U.S. 68 (1937) (libelled vessel, allegedly owned and in possession of Spain, held, in absence of State Department recognition of immunity, not immune as not having been shown to be in possession and public service of Spain) with Berizzi Bros. Co. v. Steamship Pesaro, 271 U.S. 562 (1926) (merchant ship owned and operated by foreign government held immune in spite of State Department's stated policy that merchant ships not entitled to immunity).

55. Von Mehren, supra note 41 , at 41 .

56. 318 U.S. 578 (1943) (holding courts bound by State Department's express "recognition and allowance" of claim of immunity).

57. 324 U.S. 30 (1945) (holding vessel owned by but not in possession of Mexico not immune because State Department had accepted only claim of ownership, had indicated that immunity probably not available, and had never allowed claim of immunity on ground of mere title).

58. See Ex parte Peru, 318 U.S. at 586-87; see also, e.g., 1976 REPORT, supra note 6, at 8.

This practice of looking in each case to the Executive Branch for guidance had long been developing. See, e.g., United States v. Lee, 106 U.S. 196, 209 (1881); 1976 REPORT, supra note 6, at 8; cf. infra p. 1193 (courts reluctant to deal with foreign affairs). It was generally approved, see, e.g., Cardozo, Sovereign Immunity: The Plaintiff Deserves a Day in Court, 67 HaRV. L. REV. 608, 614 15 (1954), at least to the extent of inquiring whether the defendant was in fact a recognized sovereign, see, e.g., Jessup, Has the Supreme Court Abdicated One of Its Functions?, 40 AM. J. INT'L L. 168, $168-69$ (1946)-and, under the absolute theory then prevailing, the answer to that question would normally be determinative.

In contrast, Hoffman's enshrinement of the Executive's policies, see infra note 59, gave the political branch jurisdiction over questions of law, Jessup, supra, at 169; cf. infra note 61 (discussing political character of immunity law). Such an increased reliance on Executive decisions may also be reflected in the IOIA's provisions for Executive control of IGOs. See supra p. 1170.

59. See Hoffman, 324 U.S. at 34-35, 36. That decision bound the courts to the policies of the State Department. The State Department, however, had made its only statement of policy in that case by citing two court rulings, see id. at 31-32, and had in fact attempted earlier to adopt a restrictive theory, only to be overruled by the Court, see, e.g., Cardozo, supra note 58, at 609; cf. supra note 54 (Court granted immunity in Steamship Pesaro against State Department policy). "The freedom of a foreign sovereign from being hauled into court as a defendant has . . . become part of the fabric of our law . . . solely through adjudications of this Court." National City Bank v. Republic of China, 348 U.S. 356, 358 (1955).

Since both Ex parte Peru and Hoffman were decided in the context of war, and both relied on Lee, see 318 U.S. at 588; 324 U.S. at 35 , which in turn rested on the thesis that immunity decisions "might involve war or peace," 106 U.S. at 209 , it is likely that the Court turned to the Executive for resolu- 
man rested on a political question rationale, ${ }^{60}$ those decisions effectively denied the applicability of law to dealings with foreign sovereigns. ${ }^{61}$

The State Department's adoption of the restrictive theory of immunity in $1952^{62}$ provided parties with some minimal legal standards, ${ }^{63}$ but the Department remained susceptible to political pressures. ${ }^{64}$ Also, it did not provide criteria for applying the test of immunity adopted, ${ }^{65}$ thereby leading to uncertainty and inconsistency when the courts, following Hoffman, ${ }^{66}$ endeavored to apply the new policy. ${ }^{67}$ As was to be expected with

tion of a question perceived as capable of leading to war.

60. See HolTman, 324 U.S. at 35; see also supra notes 58, 59.

61. "[O]ne reading the opinion of Chief Justice Stone in the Hoffman case might well assume that this is a subject with regard to which no body of law exists, a subject governed entirely by political considerations." Jessup, supra note 58, at 168. As Justice Powell put it, "[t]o so argue is to assume that there is no such thing as international law but only international political disputes that can be resolved only by the exercise of power." First National City Bank v. Banco Nacional de Cuba, 406 U.S. 759, 775 (1972) (concurring in plurality decision). The effect of this deference to the Executive was, thus, to stymie the trend toward subjecting sovereigns to the rule of law. See supra p. 1173.

62. This theory was officially adopted in 1952. See the Tate Letter, supra note 53. Mr. Tate argued from comity (international usage), id. at $984-85$, reciprocity (United States no longer asserted immunity in foreign or its own courts), id. at 985 , and fairness (modern equivalent of extraterritoriality, see supra note 53 ), id.

63. One commentator suggested that "the Department ... . will have to establish . . . quasijudicial procedures" to ensure "that plaintiff will be given that essential ingredient of due process, his day in court." Cardozo, supra note 58, at 617-618. Such procedures were in fact instituted. Contemporary Practice of the United States Relating to International Law, 64 AM. J. INT'L L. 631, 650-52 (1970); Weber, supra note 41, at 59 n.38. Under these procedures, foreign states initiated determinations of immunity, Weber, supra note 41, at 59 n.37; see Contemporary Practice of the United States Relating to International Law, supra, at 651, thus having the option of court or State Department determination, 1976 REPORT, supra note 6 , at 8 , which the states used to choose the more favorable forum, e.g., Weber, supra note 41, at 1-2,11-13 (for example, see id. at 1-2).

64. 1976 REPORT, supra note 6, at 8-9; Note, The Foreign Sovereign Immunities Act of 1976: Giving the Plaintiff His Day in Court, 46 FORDHAM L. REV. 543, 548-49 (1977); see, e.g., Rich v. Naviera Vacuba, 295 F.2d 24, 26 (4th Cir. 1966) (State Department suggested immunity for foreign state defendant even though suit based on commercial activities); Chemical Natural Resources v. Republic of Venez., $420 \mathrm{~Pa}$. 134, 160-61, 215 A.2d 864, 876-77, cert. denied, 385 U.S. 822 (1966) (same); see also supra p. 1172 (FSIA transferred determinations of immunity to judiciary because of fears of foreign state influence on State Department).

65. Victory Transport Inc. v. Comisaria General de Abastecimientos y Transportes, 336 F.2d 354, 359 (2d Cir. 1964), cert. denied, 381 U.S. 934 (1965); von Mehren, supra note 41, at 41. How to distinguish between commercial and governmental activities had already been found an almost impossibly difficult question in the domestic sovereignty arena. See, e.g., Owen v. City of Independence, 445 U.S. 622, 644 n.26 (1980) (dictum); O'Toole, supra note 37, at 10; cf. New York v. United States, 326 U.S. 572, 583-84 (1946) (Frankfurter, J.) (referring to "such untenable criteria as 'proprietary' against 'governmental' activities of the States") (dictum).

66. The case could be, and was, interpreted in various ways. Compare, e.g., Hoffman, 324 U.S. at 34-35, 36 (majority opinion) (courts to follow policies of State Department) and id. at 38-42 (Frankfurter, J., concurring) (case turns on foreign sovereign's lack of possession of vessel; courts should not disclaim jurisdiction otherwise belonging to them except when State Department or Congress "explicitly asserts that the proper conduct of [foreign] relations calls for judicial abstention," id. at 42) with Cardozo, supra note 58, at 616 (Court seemingly inconsistent in permitting courts to decide immunity questions when no recognition by State Department while forbidding courts to recognize immunity on new grounds not recognized by government) and Sanborn, The Immunity of Government-Owned Merchant Vessels, 39 AM. J. INT'L L. 794, 794 (1945) (majority of Court held no immunity because vessel not in possession of foreign sovereign).

67. See, e.g., Victory Transport Inc. v. Comisaria General de Abastecimientos y Transportes, 336 
the Department continuing to retain primary jurisdiction, ${ }^{68}$ the courts' efforts resulted in no definitive solution. ${ }^{69}$ Moreover, the United States continued to adhere to an absolute theory of immunity from execution. ${ }^{70}$ The FSIA was intended to deal with this specific and highly unsatisfactory situation, ${ }^{71}$ which was peculiar to the law of foreign sovereign immunity. ${ }^{72}$

Analysis of the Act's history and provisions confirms that Congress did not consider international immunities. ${ }^{73}$ In fact, the only mention of the IOIA or international immunities in the FSIA or in its official legislative history protects those immunities against possible infringement under the FSIA, ${ }^{74}$ indicating, in conjunction with Congress' careful limitation of the scope of the 1976 Act whenever it might affect closely related areas of law, ${ }^{75}$ that the legislature perceived the two Acts as capable of overlapping only at that point. Moreover, the FSIA's stated goal of depoliticizing immunities $^{76}$ is incompatible with the broad powers given the Executive in

F.2d 354, 359-60 (2d Cir. 1964) (suggesting that "the distinction is unworkable"), cert. denied, 381 U.S. 934 (1965).

68. One probable reason for the FSIA's transfer of jurisdiction back to the courts was to allow them to develop such criteria. See 1976 REPORT, supra note 6 , at $13,16$.

69. See id. at 7 (no "firm standards as to when a foreign state may validly assert the defense of sovereign immunity").

70. Von Mehren, supra note 41 , at $42-43$ \& nn.42-44.

71. 1976 REPORT, supra note 6, at 6-8, 12; see also supra p. 1172 (stating objectives of FSIA).

72. International immunities were almost invariably determined, with only two partial exceptions, solely under the IOIA and were deemed absolute. See Miller v. United States, 583 F.2d 857, 868 n.42 (6th Cir. 1978); Lutcher S.A. Celulose e Papel v. Inter-American Dev. Bank, 382 F.2d 454, 456 (D.C. Cir. 1967) (Burger, J.); Edison Sault Electric Co. v. United States, 552 F.2d 326, 336 (Ct. Cl. 1977); Soucheray v. Corps of Engineers of United States Army, 483 F. Supp. 352, 355 (W.D. Wis. 1979); Weidner v. International Telecommunications Satellite Org'n, 392 A.2d 508, 510-11 (D.C. App. 1978) (complaint filed after FSIA went into effect; court did not mention FSIA but cited District Court opinion in Broadbent, 481 F. Supp. 907 (D.D.C. 1978)); Gregoire v. Gregoire, 127 N.Y.L.J. 810,810 (1952). Only two fairly early New York state cases rested even partly on a State Department recognition. See Wencak v. United Nations, N.Y.L.J., Jan. 19, 1956, at 6 col. 7, 23 I.L.R. 509 (1956); Curran v. City of New York, 77 N.Y.S.2d 206 (Sup. Ct. 1947), affd without op'n, 88 N.Y.S.2d 924 (App. Div. 1949).

73. In all the extensive hearings, reports, and scholarly analysis of this Act-it was introduced twice, see 1976 REPORT, supra note 6, at 9-10, and the commentary is quite voluminous-the question of its possible impact on the immunity of IGOs apparently was not once directly raised. Cf. supra note 42 (FSIA's focus quite narrow). Moreover, the Act rested exclusively on the foreign sovereign immunities principles of reciprocity, see 1976 REPORT, supra note 6 , at 9, fairness, see id. at 6-7, and comity, see id. at 9 , with no mention of the necessity principle of international immunities, see infra $\mathrm{p}$. 1181 .

74. 28 U.S.C. $\$ 1611$ (a) (1976); 1976 REPORT, supra note 6, at 30-31. "The reference to "international organizations' in this subsection is not intended to restrict any immunity accorded to such international organizations under any other law or international agreement." Id. at 31 (emphasis added). Congress also noted that attachments of funds of foreign sovereigns held by IGOs "would also violate the immunities accorded to such international institutions" under the IOIA, 1976 REPORT, supra note 6 , at 30 , implying that those immunities would automatically survive the passage, and hence that the IOIA was independent, of the FSIA.

75. See supra note 42; see also 1976 REPORT, supra note 6, passim (numerous references to foreign states as objects of that legislation).

76. See supra p. 1172. 
the IOIA. ${ }^{77}$ One may safely conclude, then, that Congress, apparently considering the IOIA to be independent of the FSIA, ${ }^{78}$ expressed no clear affirmative intention to modify the 1945 Act merely by passing the 1976 legislation.

\section{The IOIA and the FSIA: The Law of Statutory Construction}

The question remains whether rules of statutory construction operate to incorporate the FSIA into the IOIA. This Note concludes that they do not.

Under general principles of statutory construction, a statute incorporating the general law on a subject also incorporates subsequent changes in that law, whereas a reference to a body of general law in a statute dealing with a specific separate issue has no such effect. ${ }^{79}$ The IOIA's removal of the reciprocity considerations ${ }^{80}$ that are the hallmark of foreign sovereign as contrasted with international immunities ${ }^{81}$ indicates, in conjunction with the arguments made earlier, ${ }^{82}$ that the IOIA is a reference statute. ${ }^{83}$ Such a characterization accords, moreover, with Congress' evident purpose of conferring a specific assortment of privileges and immunities on qualifying IGOs. ${ }^{84}$

The FSIA's reference to the IOIA is limited to one subsection; ${ }^{85}$ thus, the statements in the committee report denying that Congress intended to affect international immunities ${ }^{86}$ do not necessarily sever the remainder of the two Acts. ${ }^{87}$ United States v. Gue Lim $^{88}$ lays down the most closely applicable canon of statutory construction: the courts may not lightly presume Congress' intention unilaterally to alter an international obligation, but must rely on clear indications of a deliberate intent so to act. ${ }^{89}$ This

77. See supra p. 1170 (such powers important part of IOIA).

78. This interpretation of the FSIA corroborates the earlier reading of the IOIA as providing independently for absolute jurisdictional immunity for IGOs. See supra p. 1172.

79. See 2A J. SUTHERLAND, STATUTES AND STATUTORY CONSTRUCTION \$\$ 51.07-.08 (C. Sands 4th ed. 1972); see also In re Heath, 144 U.S. 92, 93-94 (1892); Sentell, "Reference Statutes"--Borrow Now and Pay Later?, 10 Gs. L. REV. 153, 155-56 (1975).

80. 22 U.S.C. § $288 \mathrm{f}(1976)$.

81. "[W]hereas observance of diplomatic privileges and immunities is ensured through the operation of the principle of reciprocity, an international organization has no such effective sanction." D. BOWETT, THE LAW OF INTERNATIONAL INSTITUTIONS 308 (1975); see also supra pp. 1170-71 (reciprocity not applicable to IGOs); pp. 1175-76 (analyses of foreign sovercign immunity consider reciprocity rather than functional necessity).

82. Supra pp. 1169-71.

83. See also Brief for Appellees 51, Broadbent v. OAS, 628 F.2d 27 (D.C. Cir. 1980). If the IOIA incorporated any law, it was that of international immunities. See id. at 44-45; supra p. 1170.

84. See supra pp. 1169-70.

85. 28 U.S.C. $\S 1611$ (a) (1976); see supra p. 1176.

86. See 1976 REPORT, supra note 6, at 30-31; supra p. 1176.

87. But see supra note 74 (Congress believed IOIA independent of FSIA); cf. supra pp. 1172, 1176 (FSIA not affirmatively intended to affect IOIA).

88. 176 U.S. 459 (1900).

89. See id. at 465; Cook v. United States, 288 U.S. 102, 119-20 (1933). The principle is not 
suggests that clearer language than that supplied by the FSIA ${ }^{90}$ is required to alter by operation of law alone the terms of the commitment represented by the IOIA. ${ }^{91}$

The argument for modification of the IOIA by the FSIA rests largely on simply reading the terms of the FSIA into the words of the IOIA. ${ }^{92}$ It urges only secondarily that application of the FSIA would not so interfere with the functioning of IGOs as to violate any provision for "necessary" immunities, ${ }^{93}$ and that absolute immunity is in itself undesirable. ${ }^{94}$ Consequently, the foregoing analysis vitiates that argument by showing that such a conjoint reading is hard to justify.

That conclusion is further supported by the history of judicial treatment of the IOIA as separate from sovereign immunity law. ${ }^{95}$ Between the publication of the Tate Letter in $1952^{96}$ and the passage of the FSIA in 1976, many cases analyzed the immunity of a defendant IGO in terms of the provisions of the IOIA rather than by applying the commercial/governmental distinction of the restrictive theory of sovereign immunity. ${ }^{97}$ Nor did IGOs normally request determinations of immunity from the State Department, ${ }^{98}$ although such a practice was routine among foreign sovereign defendants ${ }^{99}$-and the Department, in considering one of the few such requests, cited the IOIA in support of its determination of immunity. ${ }^{100}$

This separate treatment for nearly a quarter century suggests that international and foreign sovereign immunities were considered mutually

directly on point, for Gue Lim deals with a negotiated and ratified treaty commitment, not with unilateral legislation. In itself, the IOIA is neither a treaty nor an expression of binding international law, although it probably was intended to satisfy various treaty commitments or minimum international standards, supra pp. 1169-70. The Schooner Exchange, however, required that such commitments be renounced "in a manner not to be misunderstood." 11 U.S. at 146. See also The Paquete Habana, 175 U.S. 677, 700 (1900) ("International law is part of our law. . . .")

90. That language has been shown to support more easily an inference of intent not to modify the IOIA. See supra pp. 1176-77.

91. Similarly, in construing two sections of the Bankruptcy Code, the Supreme Court refused, for two reasons applicable here, to use the bare language of one to restrict the other. See United States v. Speers, 382 U.S. 266, 278 (1965) (no indication in language or legislative history of first section of intention to affect construction or application of second; in enacting second section, Congress considered first, evidencing "no awareness of interrelationship or inconsistency").

92. See Brief for Appellants at 4, 5, 10, Broadbent v. OAS, 628 F.2d 27 (D.C. Cir. 1980); Brief for United States as Amicus Curiae at 6-10, id.; O'Toole, supra note 37, at 11-12.

93. See Brief for Appellants, supra note 92, at 8-9; Brief for United States, supra note 92, at 810; O'Toole, supra note 37 , at 15-16.

94. See Brief for Appellants, supra note 92, at 9; O'Toole, supra note 37, at 10-11.

95. See Brief for Appellees, supra note 83 , at $48-50$.

96. Supra pp. 1173-74.

97. See supra p. 1176.

98. There were, apparently, only two exceptions. See id.

99. Weber, supra note 41, at 11-12.

100. Curran v. City of New York, 77 N.Y.S.2d 206, 209 (Sup. Ct. 1947), aff'd without op'n, 88 N.Y.S.2d 924 (App. Div. 1949). 
independent by the courts as well as by the Executive and by Congress. This Note consequently concludes that, as a matter of law, the passage of the FSIA has had no effect on the IOIA.

\section{A Proposal for Restricted Immunity under the IOIA}

The above analysis, however, demonstrates only that the law does not require modification of the IOIA by the FSIA. It does not consider the policy of restricted immunity: that, in general, IGOs may have no need of an absolute immunity that in itself is undesirable. ${ }^{101}$ Although the FSIA should not be read directly into the IOIA, ${ }^{102}$ this Note argues that Broadbent v. $O A S^{103}$ provides a jurisprudential basis for restricting IOIA immunities ${ }^{104}$ along the lines laid out by the FSIA: ${ }^{105}$ under the IOIA, IGOs should be vulnerable to suit for money damages ${ }^{106}$ when not engaged in "core" activities. ${ }^{107}$

101. The grant of immunity confers a privileged status, see supra p. 1173; infra p. 1181, which subverts the principle that legal rights entail legal responsibility, see infra pp. 1181-82, and allows the immune person to harm others with impunity, see infra pp. 1182, 1186.

102. The FSIA defines "commercial activity" in terms of the nature rather than the purpose of the activity, 28 U.S.C. $\S 1603$ (d) (1976); the legislative history looks to, for example, "a . . . contract . . . of the same character as a contract which might be made by a private person," 1976 REPORT, supra note 6 , at 16 . Such a test, by distinguishing between, for example, a developmental loan by the Inter-American Development Bank, Lutcher S.A. Celulose e Papel v. Inter-American Dev. Bank, 382 F.2d 545 (D.C. Cir. 1967), and the Canadian-United States International Joint Commission's prevention of flooding on the upper Great Lakes, e.g., Edison Sault Electric Co. v. United States, 552 F.2d 326 (Ct. Cl. 1977), discriminates arbitrarily and unacceptably against IGOs engaged in certain types of activity that, although public in purpose, could be performed by private persons.

Moreover, the FSIA does not forbid injunctive relief, which could be obtained in practice by attaching non-immune assets under $\S 1610$ and requiring compliance with the injunction as a condition for their release. Such a practice would be unacceptable as directly interfering with the independence of the IGO. Infra p. 1179.

103. 628 F.2d 27 (D.C. Cir. 1980) (Leventhal, J.).

104. This Note does not consider the status of any particular IGO under any particular agreement. Thus, agreements conferring only "necessary" immunities, e.g., O.A.S. CHARTER art. 103, Apr. 30, 1948, 2 U.S.T. 2394, T.I.A.S. No. 2361, as amended, art. 139, Feb. 27, 1967, 21 U.S.T. 607, T.I.A.S. No. 6849 , would be affected by this redefinition.

This analysis would not affect other, more specific agreements, such as the General Convention on the Privileges and Immunities of the United Nations, supra note 25, art. 2, §2, which would also escape the FSIA, see 28 U.S.C. $§ 1604$ (1976). In addition, the Executive Branch would remain free both to tailor immunities unilaterally under the IOIA, see supra p. 1170, and to negotiate more precise agreements with IGOs. Finally, the IOIA's provisions for IGO immunity from taxation, 26 U.S.C. $\$ \S 892,3306$ (c)(16), 3401(a)(5), 4253(c), 7701(a)(18) (1976), which were at the heart of IGO demands for immunity, see supra p. 1168, would survive unaltered.

105. See id. at 33-35. Judge Leventhal, treating the OAS as a government without a country, see infra note 173, read the FSIA to provide immunity for IGOs that was effectively analogous, not to the Act's restrictions, but to the immunity left by the Act to foreign sovereigns. Cf. infra pp. 1187-1190 (adapting FSIA to accommodate IGOs).

106. Because injunctions by their nature interfere (or have the appearance and capability of interfering) with the organization's conduct of its public affairs, even restricted immunity should allow only money damages, not injunctive relief. See O'Toole, supra note 37, at 10-11; infra pp. 1181, 1182 (IGOs' need to be independent of national control).

107. These are activities engaged in to perform functions specified in an IGO's charter or established by consistent practice. Accordingly, they may be deemed "central to the nature of the organiza- 
The IOIA itself demonstrates that Congress could simply say "immune" when it wanted to confer absolute immunity; ${ }^{108}$ thus, section $288 \mathrm{a}$ (b)'s more elaborate formula provides some evidence that the jurisdictional immunities of IGOs and of foreign states are somehow linked. ${ }^{109}$ The legislative history ${ }^{110}$ and the IOIA's provisions for Executive modification $^{111}$ provide evidence that Congress intended the IOIA immunities to be adaptable. In addition, the reasons underlying the FSIA's transfer of immunity determinations to the judiciary ${ }^{12}$ apply to the IOIA, ${ }^{113}$ indicating that the courts may exercise their normal power to interpret statutes in order to examine what section $288 \mathrm{a}(\mathrm{b})$ is to mean today. ${ }^{114}$ Moreover, the IOIA arguably incorporates international law ${ }^{115}$ and, hence, changes in that law under principles of statutory construction ${ }^{116}$ and of international law. ${ }^{17}$ Municipal (that is, national) courts have the duty to shape as well as to apply international law; ${ }^{118}$ thus, when Congress does not act, the courts may. ${ }^{119}$

tion and involv[ing] the conduct which it was created to conduct in order to achieve its international purposes," O'Toole, supra note 37, at 13, and directly "necessary for the fulfillment of [its] purposes," U.N. CHARTER art. 105, para. 1 (quoted supra note 22). Cf. infra p. 1187 (viewing such immunity as governmental).

108. See 22 U.S.C. § $288 \mathrm{a}$ (c) (1976).

109. Cf. supra pp. 1171-1172 (arguing similarity to as opposed to identity with foreign sovercign immunity).

110. The Senate in fact commented that engaging in commercial activities would constitute grounds for revoking the immunity of an IGO. 1945 SENATE REPORT, supra note 4, at 2; see also id. at 1-2; 1945 HOUSE REPORT, supra note 2, at 946, 948.

111. See supra p. 1170 .

112. Immunity is a legal matter that the State Department may not properly decide; the Department may be influenced by extralegal considerations; and Department decisions provide no general criteria for determining immunity. See 1976 REPORT, supra note 6, at 8-9; supra p. 1172, 1175.

113. The United States in fact filed an amicus brief in Broadbent urging judicial adoption of a restricted IGO immunity subject to determination by the courts. See Brief for United States, supra note 92, at 7, 8-10. The Justice Department almost certainly consulted the State Department before taking such a position. O'Toole, supra note 37 , at 14-15.

114. The argument made earlier, supra pp. 1176-1178, was against the direct incorporation of the FSIA into the IOIA, supra p. 1179. The FSIA may well affect the IOIA indirectly. See infra 1187$1190177-98$ (developing theory of restricted immunity on that basis).

115. See supra p. 1177.

116. See supra p. 1177.

117. Under international law, "[t]he same principle which subjects the act creative of a right to the law in force at the time the right arises, demands that the existence of the right, in other words its continued manifestation, shall follow the conditions required by the evolution of law." The Island of Palmas (or Miangas) (U.S. v. Netherlands), 2 U.N. Rep. Int'l Arbitration Awards 829, 1932 Hague Ct. Rep. 2d 83 (1928) (Huber, Arb.), reprinted in 22 AM. J. INT'L L. 867, 883 (1928). That award held that intervening changes in the law vitiated a title valid under earlier law. 22 AM. J. INT'L L. at 883-84. This doctrine is known as the intertemporal principle.

118. See, e.g., The Paquete Habana, 175 U.S. 677, 711 (1899); Banco Nacional de Cuba v. Sabbatino, 307 F.2d 845, 860-61 (2d Cir.), aff'g 193 F. Supp. 375, 381-82 (S.D.N.Y. 1961), rev'd on other grounds, 376 U.S. 398 (1964).

119. Cf. Trendtex Trading Corp. Ltd. v. Central Bank of Nigeria, [1977] 1 All E.R. 881, 889, 891-92 (Denning, L.J.) (because English law incorporates, hence changes with, international law, Court of Appeals need wait neither for House of Lords nor for Parliament to speak in order to restrict common-law rule of absolute immunity of foreign sovereigns). 


\section{A. The Law of International Immunity}

Since the Seventy-ninth Congress gave no reasons ${ }^{120}$ for its decision to confer absolute but modifiable immunity on IGOs, but did refer to the practice of other nations, ${ }^{121}$ international legal analysis ${ }^{122}$ may supply a rationale for the granting of the special privilege of immunity. ${ }^{123}$ IGOs possess whatever immunities may be "necessary for the fulfillment of [their] purposes"124 and for their independence from national control, ${ }^{125}$ as international theory and practice agree. ${ }^{126}$ This is known as the "functional necessity" test of international immunities. ${ }^{127}$ In the period after World War II, when international cooperation on a large scale was just beginning, ${ }^{128}$ the consensus was that functional necessity entailed jurisdictional immunity. ${ }^{129}$ That judgment rested on a conception of IGOs as young and vulnerable fledglings that, not being mature organizations, could not survive, much less function, without special protection. ${ }^{130}$

120. There is no specific discussion of the jurisdictional immunity provision. See 1945 HouSE REPORT, supra note 2; 1945 SENATE REPORT, supra note 4. The SAN FRANCISCO REPORT, supra note 20, supplied the reasons presented earlier, supra pp. 1169-1170.

121. Supra p. 1170.

122. See generally C. JENKS, INTERNATIONAL IMMUNITIES (1961); Lalive, L'Immunite de Juridiction des Etats et des Organisations Internationales, 84 RECUEIL DES COURS 205 (1953).

123. Cf. supra p. 1173 (immunity as asserting "a privileged position ... in the procedural sphere").

124. U.N. CHARTER art. 105, para. 1 (quoted supra note 22). The IOIA may well incorporate this standard. Supra p. 1169-1170.

125. E.g., SAN FRANCISCO REPORT, supra note 20, at 159 ("The United Nations, being an organization of all the member states, is clearly not subject to the jurisdiction or control of any one of them."); C. JENKS, supra note 122, at 18 ("International immunities are the legal device through which international action escapes national control . . . ."). The IOIA probably incorporates this principle too via the SAN FRANCISCO REPORT, see supra p. 1169-1170, or international law, see supra p. 1170; infra p. 1182 .

126. E.g., C. JENKS, supra note 122, at 17; Fedder, supra note 12 , at $62-64,69$. No scholar appears to contradict this principle. Some say that no rule of law exists, that IGOs possess only the immunities specified in their constitutive agreements; but even they immediately go on to refer to functional immunity as important in international practice. See D. BOWETT, supra note 81, at 310; I. BROWNLIE, PRINCIPLES OF PUBLIC INTERNATIONAL LAW 682 (3d ed. 1979). And international practice appears to be based on functional necessity. See PEASLEE, INTERNATIONAL GOVERNMENTAL ORGANIZATIONS: CONSTITUTIONAL DOCUMENTS (1961).

127. E.g., A. BENNETT, INTERNATIONAL ORGANIZATIONS 281-82 (1977); D. MICHAELS, supra note 46 , at $149-50$.

128. See, e.g., E. LUARD, INTERNATIONAL AGENCIES vii (1977).

129. E.g., Brief for Appellees, supra note 83, at 26-29; see, e.g., C. JENks, supra note 122, at 17, 41 (IGOs need protection against: control or interference by any one government; any one country's levying charges on international funds; prejudice or bad faith of national courts; baseless or malicious suits; conflicting legal requirements; national determination of law applicable to international organization); McKinnon Wood, Legal Relations between Individuals and a World Organization of States, 30 GROTIUS SOC., TRANSACTIONS 141, 143-44 (1945) (same).

130. Multinational corporations were never immune; and the immunity of foreign sovereigns in commercial matters has been diminishing steadily since the 1920's, supra pp. 1173-1174. Such entities are able to earn profits while enduring all the disadvantages of subjection to local jurisdiction; nor are IGOs in any case exempt from obedience to general provisions of law, see, e.g., K. AHLUWALIA, THE LEGAl STATUS, PRIVILEGES AND IMMUNITIES OF THE SPECIALIZED AGENCIES OF THE UNITED NATIONS AND CERTAIN OTHER INTERNATIONAL ORGanizations 203 (1964); Seyersted, Applicable Law 
Theorists acknowledged that legal rights, and a fortiori legal immunity, imposed legal responsibility, ${ }^{131}$ but some held that the principle of internationality ${ }^{132}$ required international rather than national adjudication. ${ }^{133}$ Such a requirement would, however, operate in practice to prohibit the adjudication of most cases. The International Court of Justice has only advisory jurisdiction over IGOs ${ }^{134}$ and is not designed to try their ordinary disputes with individuals. The internal tribunals established by many organizations ${ }^{135}$ have only limited jurisdiction, ${ }^{136}$ present the appearance of the denial of justice, ${ }^{137}$ and have been accused of succumbing to bias in practice. ${ }^{138}$ Waivers, arbitration agreements, and similar measures are unsatisfactory: whether they are granted is entirely within the discretion of the organization; ${ }^{139}$ nor are they available in ordinary tort cases. And relying on the state of the injured person to negotiate on his behalf interposes, as an additional barrier to any recovery, the discretion of a government that already has been found unacceptably heedless of individual injuries.

and Competent Courts in Relations Between Intergovernmental Organizations and Private Persons, 122 RECUEIL DES COURS 427, 462-63, 545 (1967, III). The problem, then, was the perceived weakness of IGOs; their inability to choose profitable areas in which to conduct their prescribed functions argues only for immunity restricted to those functions.

131. E.g., C. JENKS, supra note 122, at 41; Eagleton, International Organization and the Law of Responsibility, 76 RECUEll DES COURS 323, 385 (1950); Brief for Appellees, supra note 83, at 37-38.

132. That is, the freedom of the IGO from national control. Although this concept has a normative component, see, e.g., C. JENKS, supra note 122, at 18; Brief for Appellees, supra note 83, at 38, it is fundamentally a corollary of functional necessity, e.g., C. JENKS, supra note 122, at xxxviii, 17, 26; see also supra note 46 (pragmatic rather than normative considerations now determinative), since other governments would be reluctant to participate in an IGO controlled by one country.

Thus, this principle argues for immunity only to the extent required by practical necessity, which may be determined by analyzing the needs and possible responses of the IGO and its members. This task is within the capability of a national judiciary. See infra pp. 1184, 1185; see also infra p. 1184 (task assigned to judiciary by legislative and executive branches).

133. E.g., C. JENKS, supra note 122, at 18, 26.

134. See I.C.J. STAT. arts. 34, 65. Although Eagleton describes a complicated maneuver whereby disputants may arrange to obtain binding judgments from the ICJ, Eagleton, supra note 131, at 41820 , the need for such legal sophistication makes the suggested relief inadequate for many if not most plaintiffs.

135. The OAS itself, for example, has such a tribunal. Brief for Appellees, supra note 83, at 8-9. The practice is fairly common. M. AKEHURST, THE LAW GOVERNING EMPLOYMENT IN INTERNATIONAL ORGANIZATIONS 4-5 (1967).

136. They usually are designed to deal with internal matters only. See Brief for Appellees, supra note 83 , at 54 .

137. See, e.g., Fasla v. Secretary-General of the UN, 54 I.L.R. 351, 373, 381 (1979) (plaintiff claimed loss of job through supervisors' gross negligence in evaluating his performance; although tribunal found for him on merits, it three times refused to order reinstatement instead of severance pay); M. v. Organisation des Nations Unies, 45 I.L.R. 446 (1972) (UN admitted its troops had looted and burned plaintiff's property, but refused to award more than 100,000 francs in "reparation" for claimed loss of $3,799,675$ francs).

138. See O'Toole, supra note 37 , at $4,14 \mathrm{n} .39$.

139. Although the organization may exercise this power with restraint, sec, e.g., Preuss, Immunity of Officers and Employees of the United Nations for Official Acts: The Ranallo Case, 41 AM J. INT'L L. 555, 557-58, 577-78 (1947), the possession of such power is itself undesirable. Cf. K. LLEWELLYN, THE COMMON LAW TRADITION 362 (1960) ("massive and almost terrifying jug-handled character" of form contracts). 
This unavailability of international remedies urges that municipal courts, already charged with shaping international law, should not be forbidden to try suits against IGOs on the ground of their international status alone. ${ }^{140}$

The question, then, is whether IGOs now need the protection of an immunity available to no other entity; whether their situation is so changed that the law ought to change as well. ${ }^{141}$ At present there is no consensus that absolute jurisdictional immunity is necessary. ${ }^{142}$

\section{B. Considerations Governing International Immunity}

Three identifiable groups are directly interested in the jurisdictional position of IGOs: the organizations themselves; the parties with whom they interact; and the nations in whose territory they operate. IGOs are indispensable in a world in which problems and potentials extend beyond individual nations. ${ }^{143}$ Accordingly, the law must endeavor not to impede their intended operations ${ }^{144}$ and, as a corollary, must protect their independence in both appearance and reality from the control of any one nation. ${ }^{145}$ The parties dealing with IGO ${ }^{146}$ are, here, considered to be private individual or corporate persons; they may be taken to act primarily for themselves, although they may incidentally benefit or seek to benefit others. The nations concerned, powerful compared to either IGOs or private persons standing alone, ${ }^{147}$ seek to regulate those activities of both IGOs and private persons that those governments feel affect their interests.

The interests of these three parties must be taken into account to devise a rule that is both politically workable ${ }^{148}$ and legally acceptable. ${ }^{149}$ The

140. See Seyersted, supra note 130, at 435; cf. Eagleton, supra note 131, at 395-98 (possibility of plaintiffs national state not knowing whom to sue if justice denied only reason given for foreclosing local jurisdiction); supra note 132 (if internationality not required as normative matter, national courts capable of necessary practical calculations).

141. See C. JENkS, supra note 122, at 45, 151-52; P. JESSUP, A MODERN LAW OF NATIONS 15052 (1948); cf. supra p. 1180 (IOIA as incorporating changes in international law).

142. See I. BROWNLIE, supra note 126 , at 618 .

143. A. BENNETT, supra note 127, at 16-17; E. LUARD, supra note 128, at vii-ix, 2-5; see D. BOWETT, supra note 81, at 308.

144. See supra p. 1181.

145. Sec supra pp. $1181,1182$.

146. These parties include the recipients of IGO-conferred benefits and foreign sovereigns engaging in activities that are commercial under the FSIA.

147. E.g., E. LUARD, supra note 128, at 288; see supra p. 1177. In any case, there is little an IGO can do to discipline a contributing as opposed to a recipient state; and the United States is a large contributor. See The Intergovernmental Organizations Related to the United Nations, 31 Y.B. U.N. 1067-1175, U.N. Pub. Sales No. E.79.1.1 (1977) [hereinafter cited as The Intergovernmental Organizations]; infra pp. 1184-85.

148. The rule adopted should operate in practice to facilitate international intercourse. McDougal \& Reisman, The Prescribing Function: How International Law is Made, 6 YALE STUD. WORLD PUB. ORD. 1 (1981). Thus, it should be politically acceptable, so as to encourage compliance rather than evasion. This is especially necessary in international law, which lacks an authoritative institutional 
problem of balancing these interests may be simplified, however, by making use of two bodies of governmental immunity law: foreign and domestic sovereign immunity in United States law. ${ }^{150}$

\section{Foreign Sovereign Immunity}

There is less justification for absolute international than for absolute foreign sovereign immunity. Reciprocity considerations, extended to include retaliation of any type, ${ }^{151}$ were crucial in deciding that the Executive Branch had jurisdiction over immunity decisions. ${ }^{152}$ Yet the Executive itself has found that most cases, even against foreign sovereigns, do not involve such essentially political matters as to require decision by nonlegal processes $^{153}$ that afford little protection to private persons against unnecessary subordination of their interests to those of the governing body. ${ }^{154}$ In enacting the FSIA, which authoritatively transfers jurisdiction over immunity decisions to the courts, Congress has agreed with this judgment.

In addition, an IGO has relatively little scope for adverse responses to actions taken by the United States: it can cease or restrict operations in

enforcement mechanism.

149. The rule of absolute jurisdictional immunity for IGOs was, at bottom, a political concession to the member nations to ensure the viability of IGOs. See supra p. 1181. The private persons whose interests were most directly affected and were abrogated had no voice in the decision. Such a procedure is repugnant to the judicial process. It is desirable, then, to reconsider, in the light of present conditions, the necessity for this grant of immunity. See Note, International Organizations: Immunity-Broadbent v. Organization of American States, 21 HARV. INT'L L.J. 552, 560-61 (1980) (urging such re-examination); Note, International Organizations-Immunity-Personnel Decisions of an International Organization are not "Commercial Activities" and Thus May Not Form the Basis for an Action Against the Organization, 20 VA. J. INT'L L. 913, 922-23 (1980) (same). Because Congress itself suggested that absolute jurisdictional immunity could be modified, such an inquiry is not impermissible. Supra pp. 1179-80.

150. Domestic law analogies may assist in formulating rules of domestic law, $c$. Lauterpacht, supra note 50, at 237 (linking foreign and domestic sovereign immunity), within the limits of international law, see supra p. 1177 (domestic law must conform to international law if at all possible). $C$. Note, The Jurisdictional Immunity of Foreign Sovereigns, 63 YALE L.J. 1148, 1165-67 (1954) (immunity for foreign government should be put on approximately same basis as that of domestic government).

151. If reciprocity is defined narrowly, as involving the same type of behavior-for example, grants of immunity-by both parties, courts may feel themselves competent to decide cases, as with The Schooner Exchange. But if reciprocity is defined broadly to include responses of any type, including retaliatory actions of a wide variety, courts may perceive the question as political and hence the responsibility of the Executive. See, e.g., Ex parte Republic of Peru, 318 U.S. 578, 588 (1943); cf. Note, Sovereign Immunity in the Supreme Court: Using the Certiorari Process to Avoid Decisionmaking, 16 VA. J. INT'L L. 903 (1976) (Court hoping for legislative action on complex immunity question). See generally Baker v. Carr, 369 U.S. 186, 211-12 (1962) (in deciding justiciability, courts to analyze foreign relations question "in terms of the history of its management by the political branches, of its susceptibility to judicial handling in the light of its nature and posture in the specific case, and of the possible consequences of judicial action").

152. Supra p. 1174.

153. See supra p. 1172.

154. See supra pp. 1172, 1175. Nor should diplomats, whose constituency is the nation as a whole, be expected carefully to protect the rights of individuals. 
the United States, attempt to expel the United States, or protest through diplomatic channels, including those within the organization. Since the first two measures are quite drastic, it is unlikely that IGOs will take such actions unless severely provoked; $; 155$ and diplomatic channels remain open. ${ }^{156}$ IGOs are, however, more vulnerable to United States actions than are foreign governments; ${ }^{157}$ consequently, the law ought to protect IGOs from overly intrusive or burdensome intervention caused by the legal processes of the United States.

Moreover, since IGOs are vehicles for cooperation rather than competition with the United States and its citizens, there is less reason to fear judicial bias against an IGO defendant, ${ }^{158}$ and correspondingly less reason for IGOs or their member governments to feel that judicial decisions unduly favor the United States. Finally, since the law to be enforced is either local or international, ${ }^{159}$ not foreign, judges should be able to apply familiar standards in adjudicating cases. ${ }^{160}$ Comparing international with foreign sovereign immunity law thus argues against the retention of absolute international immunity, but for the provision of politically necessary immunities.

\section{Domestic Sovereign Immunity}

Less justification also exists for absolute international than for absolute domestic sovereign immunity. That the United States government cannot be sued without its consent in federal courts is probably due to its being the government from which those courts derive their powers. ${ }^{161}$ This

155. See also supra note 147 (little IGO can do against United States, which is large contributor).

156. Such channels of course include the complicated pressures an IGO's members can bring to bear within the organization itself, as well as more formal avenues of protest.

157. Not only do IGOs depend to a great extent on United States financial support, see supra note 147 , they are vulnerable to lobbying and other persuasive efforts by persons within the organization, see also supra note 156 . Foreign sovereigns are vulnerable in neither of these ways.

158. Judges, of course, guard against bias in any case. E.g., Banco Nacional de Cuba v. Sabbatino, 307 F.2d 845, 860 (2d Cir. 1962), rev'd on other grounds, 376 U.S. 398 (1964). The fact of cooperation does, however, make the task of guarding easier; that Sabbatino itself, which set aside as discriminatory an action of the government of Communist Cuba against United States banks, was reversed by the Supreme Court as having erroneously asserted United States jurisdiction over a foreign country, 376 U.S. at 398, suggests that the judicial guard may sometimes drop.

159. See, e.g., Brief for Appellees, supra note 83, at 37-38; Seyersted, supra note 130, at 435.

160. In deciding cases involving foreign nations, different normative systems and expectations must be taken into account. See, e.g., Deutsch, Law, Capitalism, and the Future, 28 U. FLA. L. REV. $309,342-44$ (1976). In domestic law, on the other hand, judges are free to enforce the norms of a single, reasonably coherent community, which both restrains a "nonjudicial" exercise of discretion and provides the "judicially discoverable and manageable standards" necessary for justiciability, Baker $v$. Carr, 369 U.S. 186, 217 (1962).

161. E.g., Chisholm v. Georgia, 2 U.S. (2 Dall.) 419, 478 (1793) ("in cases of actions against the United States, there is no power which the courts can call to their aid"); THE FEDERALIST NO. 81, at 602 (A. Hamilton) (J. Hamilton ed. 1871) ("It is inherent in the nature of sovereignty, not to be amenable to the suit of an individual without its consent."). This is probably the source of the pronouncement, carried to this country from England, that "The King can do no wrong," which has 
clearly is not true of IGOs; ${ }^{162}$ and in any case domestic sovereign immunity has gradually been surrendered to a great extent. ${ }^{163}$

Moreover, because an IGO, which is composed of foreign states and largely staffed by international civil servants, owes no loyalty to its host nation, ${ }^{164}$ it may present a threat to that nation's security ${ }^{165}$ and even to its ability to govern its own citizens. ${ }^{166}$ Accordingly, a host nation needs to be able to set enforceable limits to the sphere of the IGO's activity. ${ }^{167}$ But the IGO is also relatively powerless and thus needs some protection against undue interference ${ }^{168}$ by such a nation, even though it is acting with rather than against that nation. ${ }^{169}$ Thus, comparison with domestic immunity also argues against absolute immunity, but for immunity on suitable terms, that is, as narrow as allowed by functional necessity. ${ }^{170}$

often been considered the rationale for sovereign immunity even in the United States, see, e.g., Owen v. City of Independence, 445 U.S. 622, 645 n.28 (1980).

By constitutional amendment, states are immune from suit in federal courts. U.S. CONST. amend. XI; Hans v. Louisiana, 134 U.S. 1 (1890). Conversely, the federal government is immune on federalism grounds from suit in state courts. Kansas v. United States, 204 U.S. 331 (1907) (alternative holding).

162. The United States government is, of course, one of the members of any IGO. See supra p. 1167. Nonetheless, the IGO does not possess the sovereignty of the United States over United States courts; moreover, it derives its immunity from the express mandate of the United States government, not via common law from the immunity of its member governments, supra p. 1168; see also supra p. 1170 .

163. See, e.g., the Tucker Act, ch. 359, 24 Stat. 505 (codified in scattered sections of 28 U.S.C.); the Federal Tort Claims Act, tit. IV, ch. 753, 60 Stat. 842, as amended (codified in scattered sections of 28 U.S.C.); the Public Vessels Act, 46 U.S.C. $\$ \$ 781-790$ (1976); the Suits in Admiralty Act, 46 U.S.C. $\$ \$ 741-752(1976)$.

164. E.g., D. MICHAELS, supra note 46, at 28; see, e.g., the IOIA Letters, supra note 16, at 1563.

165. See, e.g., supra p. 1170.

166. Cf., e.g., Keeney v. United States, 218 F.2d 843 (D.C. Cir. 1954) (because employed by UN, defendant United States citizen held not in contempt of Congress for refusing to answer questions of House Committee on Un-American Activities).

167. This has been achieved with respect to IGO employees by holding that, because certain activities cannot be deemed to fall within the scope of their official functions, the employees are subject to, for example, criminal prosecution for espionage. United States v. Egorov, 222 F. Supp. 106 (E.D.N.Y. 1963); United States ex rel. Casanova v. Fitzpatrick, 214 F. Supp. 425 (S.D.N.Y. 1963); United States v. Melekh, 193 F. Supp. 586 (N.D. Ill. 1961); United States v. Coplon, 84 F. Supp. 472 (S.D.N.Y. 1949).

168. See supra pp. 1182,1183 . Because each IGO has a financial situation and an assortment of internal constituencies, composed of its member states and its beneficiaries, that are peculiar to it, the issue of what constitutes "undue" interference may well be decided differently in different cases. For this reason, the Executive may find it desirable to specify particular immunitics to fit the situation of an individual IGO. Cf. supra p. 1179 (President would retain power to tailor IOIA immunity under restrictive theory).

169. Cf. supra p. 1185 (cooperation as reducing potential judicial bias). Domestic governments themselves need some protection against their own citizens. See Butz v. Economou, 438 U.S. 478, 50607 (1978); Gregoire v. Biddle, 177 F.2d 579, 581 (2d Cir. 1949) (L. Hand, J.), cert. denied, 339 U.S. 949 (1950).

170. E.g., D. BOWETT, supra note 81, at 308; O'Toole, supra note 37, at 3 \& n.9. Such an emphasis on restricting immunity accords with the trend against immunity, see supra p. 1173, as well as with the primacy of law, see supra notes 61,149 . 


\section{A Proposal for Restricted Jurisdictional Immunity}

The question, then, is how to prescribe in legal terms the immunity that IGOs in general require as a matter of practical necessity. In the absence of actual IGO vulnerability, ${ }^{171}$ this problem may be resolved by examining the organizations' needs in the light of their intended functions.

\section{The Public/Private Distinction}

Because they perform specified public services under authority granted and controlled by sovereign states, IGOs probably may best be treated as agencies of a hypothetical world government, ${ }^{172}$ the approach implicitly adopted by Judge Leventhal in Broadbent. ${ }^{173}$ Several considerations ${ }^{174}$ then suggest that IGOs should be absolutely immune when acting as government agencies, ${ }^{175}$ that is, when directly engaged in their "constitutive" or "core" activities. ${ }^{176}$

Such a formulation of restricted immunity nicely balances the competing interests of the various groups. The independence and operations of IGOs as IGOs are protected; to the extent that the organization acts as a private person, other private persons and the host nation may assert their legal rights against it on that basis. This assertion of only sovereign immunity is, then, the essence of the functional principle of immunity.

\section{Adapting the FSIA}

Since immunity as government is also the heart of the FSIA commer-

171. IGOs with miniscule budgets probably would suffer material injury if not absolutely immune, see, c.g., The Intergovernmental Organizations, supra note 147; cf. supra note 168 (each IGO's situation different), and ought to retain that immunity. Courts should determine the actual need for immunity on a case-by-case basis, using only public or freely voluntecred records to avoid a burdensome inquiry merely to determine whether jurisdiction exists.

172. Such an analogy is not wholly accurate; for example, no actual world government exists. Nevertheless, the relation of IGOs to their constituent states is sufficiently similar to that of the federal to the state governments to provide an illuminating analogy. See, e.g., C. JENKS, supra note 122, at $17-18$.

173. See Broadbent, 628 F.2d at 34-35

174. Chief among these is the need to avoid national control and to prevent any outside direction of their activities. See supra p. 1181.

175. Sec, e.g., FSIA, 28 U.S.C. $\$ \S 1604,1605$ (1976) (foreign sovereigns immune except when acting in various non-governmental capacities); New York v. United States, 326 U.S. 572, 582 (1945) (Frankfurter, J.) (immunity may apply to activities "uniquely capable of being [carried on] only by a State . . . "); Victory Transport Inc. v. Comisaria General de Abastecimientos y Transportes, 336 F.2d 354, 360 (2d Cir. 1964) (immunity should extend to "strictly political or public acts"); cf. supra p. 1186 (UN personnel not immune from prosecution for espionage because such activity not within scope of their official duties).

176. O'Toole, supra note 37 , at 13; supra p. 1179. This meets the requirements of the writers on this subject, see supra p. 1181, who apparently did not contemplate that IGOs would engage in commercial activities. Cf., e.g., C. JENKS, supra note 122, at 151-52 (restricted immunity might become appropriate in that event); 1945 SENATE REPORT, supra note 4, at 2 (engaging in such activity one ground for withdrawing IGO's immunity). 
cial/governmental distinction, ${ }^{177}$ and since the IOIA itself indicates that foreign sovereign immunity is relevant to international immunities, ${ }^{178}$ the specific provisions of the former statute are authority for a means of translating a principle of core function immunity into rules of law. ${ }^{179}$ Judge Leventhal's apparent distortion of the language of the 1976 Report $^{180}$ in defining restricted IGO immunity thus turns out to be proper procedure: rather than read the legislative history literally, he allowed the OAS to deal with personnel subject to $\mathrm{it}^{181}$ without interference from United States courts, ${ }^{182}$ an ability retained by foreign sovereigns under the FSIA. ${ }^{183}$

Such an interpretation of the FSIA provides specifically for jurisdictional immunity for matters relating to (international) civil service employees-and, by extension, an IGO's internal administration ${ }^{184}$ - and for the equivalent of "foreign assistance program[s]," tive functions, ${ }^{186}$ of the IGO. The latter activities are of an inherently noncommercial nature: like national public assistance, they directly benefit the entities the organization was created to help, not the IGO itself. ${ }^{137}$

177. See 1976 REPORT, supra note 6, at 14, 16-17.

178. See supra pp. 1171-72, 1179-80.

179. The law of domestic sovereign immunity attempted to apply a similar distinction between governmental and proprietary functions. See supra note 65. Unfortunately, that law is too unclear to provide much guidance here. Id.

180. The judge construed the 1976 REPORT, supra note 6 , at 16 , to exclude its specific language that employment of United States citizens was a commercial activity. He justified this reading by finding that provision "not applicable to international organizations" because, unlike foreign sovereigns, they possess no citizens of their own through whom "to conduct 'governmental' matters." 625 F.2d at 34. While his logic underscores the FSIA's lack of consideration of international immunities, supra p. 1176, it scarcely compels the conclusion that, if the FSIA is incorporated into the IOIA, Congress' explicit language protecting United States citizens, 1976 REPORT, supra note 6, at 16, counts for nothing.

181. IGO employees must be treated as internationals even when they are United States citizens. D. MICHAELS, supra note 46, at 28; see also M. AKEHURST, supra note 135, at 5-6; supra note 166.

182. 628 F.2d at 34. The underlying principle is that one state may not interfere in matters wholly within the jurisdiction of another government. Home Ins. Co. v. Dick, 281 U.S. 397, 408, 410 (1930); see also Allstate Ins. Co. v. Hague, 449 U.S. 302, 310-11, 312-13 (1981).

183. See 1976 REPORT, supra note 6, at 16. See id. Such immunity is unanimously recommended. See, e.g., Brief for United States, supra note 92, at 11-18; cf. O'Toole, supra note 37, at 10-11 (urging restriction of immunity but acknowledging injunctive relief should not be available to employee plaintiffs). It also appears necessary in order to protect the IGO from pressures exerted through its $\mathrm{em}$ ployees. Cf. Keeney v. United States, 218 F.2d 843, 845 (D.C. Cir. 1954) (needs of employees affect IGO's conduct of its affairs).

184. Seyersted, supra note 130, at 435; cf. Banco Nacional de Cuba v. Sabbatino, 376 U.S. 398, 414, 428-37 (1964) (United States courts have no jurisdiction over governmental actions "fully executed within the foreign state").

185. 1976 REPORT, supra note 6, at 16.

186. See also supra pp. 1179,1187 (defining constitutive functions and suggesting immunity for such activities as governmental); supra p. 1187 (finding such immunity functionally necessary). Such a definition looks to the nature rather than the purpose of the act, as required by the Foreign Sovercign Immunities Act, see 28 U.S.C. § 1603(d); see also 1976 REPORT, supra note 6, at 16.

187. The contributions of the members are made to further such purposes; they should not, and may not if the organization is to be politically viable, cf. supra note 132 (other countries reluctant to participate in IGO controlled by one state), be diverted into other payments benefiting one state contrary to the intention of the other states, cf. supra note 129 (that possibility one reason for absolute 
Immunity for these activities also stems from the potential plaintiff's probable expectation that the IGO itself ultimately controls such matters. ${ }^{188}$

When, however, the transaction involves a private person seeking an ordinary commercial profit, the FSIA classifies it as commercial in nature. ${ }^{189}$ The gist of the Act is that a transaction otherwise commercial does not become public merely because made by a government for a public purpose; ${ }^{190}$ such transactions, although they may be necessary for core activities to proceed, directly benefit the IGO. ${ }^{191}$ Thus, a substantially routine contract for the construction of an office building, ${ }^{192}$ the shipment of relief foodstuffs, ${ }^{193}$ or the purchase of medical supplies to be distributed for public purposes would all subject the IGO to the jurisdiction of United States courts. ${ }^{194}$ Moreover, the private contractor involved probably views the transaction as commercial, ${ }^{195}$ if the organization does not wish to ac-

jurisdictional immunity). This is one of the chief reasons for exempting IGOs from national taxation, see, e.g., 13 Ditist' (Ol: INTHENATIONAl. LAW 100-02 (M. Whiteman ed. 1968), which in turn was one of the chief purposes of the IOI $\Lambda$ itself, see supra p. 1168.

188. Thus, a loan made by an IGO in fulfillment of its public purposes would be immune, see supra p. 1179; cf. 1976 REPOR', supra note 6, at 16 ("mere participation in a foreign assistance program . . . is an activity whose essential nature is public or governmental"), whereas a loan made by a commercial bank, which seeks to earn profits and by definition has private purposes, see supra $\mathrm{p}$. 1183, would not, 1976 RH:POR', supra note 6, at 10. Similarly, under the civil-law principle of administrative contracts, which are contracts of so public a nature that the parties must be deemed to have contemplated that the governmental party not be wholly bound by the contract's terms, a contract with a public purpose will not be enforced against a sovereign. See, e.g., Texaco Overseas Petroleum Co. v. Libyan Arab Rep. (1977) (Dupuy, Arb.), reprinted in 17 INT'l. LE(iNL MAT. 1 (1978).

189. See 1976 REPORI', supra note 6, at 6-7, 9, 10,14, 16-17. Thus, an IGO allempting to earn a commercial profit, even from core activities, should not be immune: it would have entered into competition with private persons. Cr. supra note 52 (foreign sovereign not immune when acting as private person).

190. 1976 REPORT, supra note 6, at 16. Even if IGOs do not seek to achieve political ends by trading, they are availing themselves of the benefits provided by the marketplace and laws of the host nation, and hence should be subject to its jurisdiction. See, e.g., Hanson v. Denckla, 357 U.S. 235, 253 (1958); International Shoe Co. v. Washington, 326 U.S. 310, 319-20 (1945).

191. No unacceptable intrusion would result even in the case of a contract for materials necessary to the conduct of the IGO's core activities. The IGO is, in this respect, acting in no purely governmental capacity since it is the primary beneficiary of the transaction. Cf. supra p. 1183 (private parties act for own benefit). There is no reason to presume an IGO less capable than any other entity of fending for itself in commercial matters, but see supra p. 1186 (vulnerable IGOs should retain immunity), or to impose knowledge of a secondary public purpose on a private person entering into what seems a routine supply contract, $c f$. supra note 188 (administrative contracts those private persons would expect to be public in nature).

Moreover, the IGO retains control over the subject matter of the contract until it is actually delivered to the recipient. Since IGOs are acknowledged to be subject to law, which in turn holds them responsible to the other contracting party, and since the IGO has chosen to enter into this agreement, there seems little reason to foreclose judicial jurisdiction. See supra pp. 1181-82.

192. CT. Dumont \& Besson v. Association de la Muette, 47 I.L.R. 345 (1974) (contractors building IGO oflices sued for noise; court found it had jurisdiction).

193. Cr. International Refugee Org. v. Republic S.S. Corp., 189 F.2d 858 (4th Gir. 1951) (IGO suing for breach of contract for shipment of food). Restricted immunity would give a shipper a corresponding right to sue, for example, for nonpayment.

194. See generally 1976 RFPORT, supra note 6, at 16.

195. In such cases, the FSI $\Lambda$ suggests that a foreign sovereign will forfeit an otherwise available immunity. See 28 U.S.C. $\$ 1605$ (b) (1976) (so providing with regard to maritime liens); 1976 RE- 
cept his view, it may explicitly contract to alter the normal procedures of law. ${ }^{196}$ That such a transaction should not give rise to immunity thus gives effect to the expectations of the party with less reason to suspect his disadvantage and hence less ability to bargain for a contract to his liking. ${ }^{197}$

The FSIA's logic applies even more forcefully to ordinary tort plaintiffs, who are unable to bargain in advance for waiver of immunity and who have entered into no profitable agreement under which they might have waived their normal right to sue for injury. Merely allowing suit in tort against an IGO seems unlikely to constitute overly intrusive interference with its core activities. ${ }^{198}$ And the need to protect private persons against nonconsensual, tortious injury appears strong enough to justify what interference might occur.

But the plaintiff in a governmental tort action, ${ }^{199}$ say for deliberate misuse of the IGO's fundamental powers, is in a different situation. Since the organization would normally be immune from such suits even under restricted immunity law, the question is whether such an allegation of misconduct should be deemed to remove the action involved so far from the sphere of governmental behavior as to confer jurisdiction. ${ }^{200}$ Allegations of intentional or negligent abuse of power are easily made and, in contrast to contract and ordinary tort pleas, hard to resolve by motion for summary judgment: ${ }^{201}$ because jurisdiction itself could not be found without a decision on the merits of the case, almost all such suits would have to be tried. The threat of trial before a jury and judge loyal to the host nation ${ }^{202}$ for

PORT, supra note 6, at 21-22 (same); cf. supra notes 188, 191 (private person's expectations factor in immunity determinations).

196. Clauses effectively providing for immunity are not illegal, even when benefiting private persons, if bargained for by parties of relatively equal strength. D.H. Overmyer Co. v. Frick Co., 405 U.S. 812 (1972) (sustaining confession-of-judgment clause).

197. An initial position of nonimmunity would leave both parties in relatively equal bargaining positions. Cf. supra p. 1182 (immunity allows one-sided contracts).

198. Insurance is readily available; and the UN itself has routinely waived immunity in such cases for over twenty years, see Ehrenfeld, United Nations Immunity Distinguished from Sovereign Immunity, 52 AM. SOC. INT'L L. PROC. 88, 90 (1958).

199. Such actions involve abuse of governmental power rather than private misconduct. See, e.g., Bivens v. Six Unknown Named Agents of Fed. Bureau of Narcotics, 403 U.S. 388 (1971); Bell v. Hood, 327 U.S. 678 (1946).

200. This question is distinct from whether the officials themselves may be sued for such misconduct. The IGO may be thought legally incapable of acting in violation of its charter or of applicable law, so that the only possible defendants would be the officials involved. Cf. Ex parte Young, 209 U.S. $123,159-60$ (1908) (use of name of state official to enforce unconstitutional act held conduct without authority of and not affecting state in governmental capacity). The conduct of its agents is, however, the responsibility of the IGO; their use of its power may have caused the injury complained of; the IGO having control of the evidence, discovery of the proper individuals may be difficult; and its assets may be more plentiful and more readily available. Thus, in the absence of other considerations, the IGO, as well as its agents, should be a proper defendant in such a suit.

201. Allegations of intent normally present genuine issues of material fact, $6 \mathrm{~J}$. MOORE \& J. LUCAS, MOORE'S FEDERAL PRACTICE I 56.17[41.-1] (2d ed. 1980), which may not be resolved by summary judgment. See FED. R. CIV. P. 56.

202. Such a jury might well be biased against the non-national IGO. The possibility of bias 
what might well be significant damages ${ }^{203}$ would give a plaintiff too much leverage to coerce the organization to act in his favor, would chill the organization in its performance of its essential functions, and would present a plausible appearance of attempted domination of the organization by the host nation. Such a rule would, as well, open the door to direct intervention in the core activities of an IGO. ${ }^{204}$ The functional necessity rule, then, mandates denial of relief even to genuinely and severely injured plaintiffs. ${ }^{205}$

\section{Application and Effect}

The outline above provides for immunity only for the IGO's constitutionally prescribed governmental activities, ${ }^{206}$ including transactions such as loans that would be private if made for profit. Ordinary business contracts directly benefiting the IGO itself, even when executed to make governmental activities possible, and ordinary torts carry with them ordinary liability to suit. Victims of governmental torts, however, have no legal remedy. The fundamental test is whether suit would so interfere with the organization's performance of its intended functions as to hamper its independent operation. ${ }^{207}$

Under this theory of restricted international immunity, Broadbent, ${ }^{208}$ Tuck v. Pan American Health Organization, ${ }^{209}$ and Weidner v. International Telecommunications Satellite Organization, ${ }^{210}$ all involving suits by former employees, correctly asserted the immunity of the defendant IGO. Lutcher S.A. Celulose e Papel v. Inter-American Development Bank ${ }^{211}$ was also correct in holding the defendant IGO immune from a suit related

against residents even of sister states is largely responsible for the diversity jurisdiction of federal courts, U.S. CONST. art. 3; 28 U.S.C. $\$ 1332$ (1976), and for the provision that an out-of-state defendant sued in a state court may remove the trial to a federal court having original jurisdiction, 28 U.S.C. $\S 1441$ (1976). E.g., Martin v. Hunter's Lessee, 14 U.S. (1 Wheat.) 304, 347 (1816) (Story, J.).

203. Damages might be measured by, for example, the amount of a grant to a third party plus incidental or consequential damages, see, e.g., Lutcher S.A. Celulose e Papel v. Inter-American Dev. Bank, 382 F.2d 454 (D.C. Cir. 1967); and punitive damages might be available in tort actions.

204. For example, an IGO's fear of paying damages for governmental activities might cause it so to restrict those activities as to have an effect similar to enjoining those activities; such a fear could, consequently, interfere with the core activities of IGOs. See supra p. 1179.

205. Cf. Gregoire v. Biddle, 177 F.2d 579, 581 (2d Cir. 1949) (L. Hand, J.) (principle of domestic government independence requires toleration of some evil), cert. denied, 339 U.S. 949 (1950).

206. See supra pp. 1179, 1187, 1188.

207. In cases not covered by the specific rules given above, the burden of proof of vulnerability should rest on the IGO. The organization should, however, be able to rely solely on public or freely volunteered records in meeting that burden. See supra p. 1186.

208. 628 F.2d 27 (D.C. Cir. 1980).

209. 668 F.2d 547 (D.C. Cir. 1981). This case appears to concern an attorney for the employees of an IGO.

210. 392 A.2d 508 (Ct. App. D.C. 1978).

211. 382 F.2d 545 (D.C. Cir. 1967) (Burger, J.). 
to a loan made in pursuance of its core activities; and the International Joint Commission cases ${ }^{212}$ rightly held that body immune from actions for flood damage caused by its regulation of the water level of the Great Lakes, a constitutive function. On the other hand, Menon v. Weif ${ }^{13}$ and Means v. Means, ${ }^{214}$ which forbade actions against the United Nations for garnishment of employees' wages for the support of their estranged wives and children; probably were incorrectly decided; if the employee himself is not immune, ${ }^{215}$ the organization's operations probably would not be unacceptably compromised by turning over part of his salary to a third party in satisfaction of a judgment obtained against him. ${ }^{216}$ Even the plaintiff in $M$ v. Organisation des Nations Unies, ${ }^{217}$ a suit growing out of the United Nation's peacekeeping activities in the former Belgian Congo, probably should have obtained a trial, since the United Nations had admitted liability but had not formally determined damages. ${ }^{218}$

The proposed restricted immunity, then, goes far toward affording relief to injured private persons while preserving the ability of intergovernmental organizations to operate independently and effectively to fulfill their purposes. It also preserves both the language and intent of the IOIA and the FSIA while meeting the requirements of international law.

\section{Relief Against Immune IGOs}

The above theory of restricted immunity leaves remediless three significant groups of plaintiffs: IGO employees; participants in governmental activities; and victims of governmental torts. By hypothesis these plaintiffs are United States subjects ${ }^{219}$ or base their suits on actions occurring within

212. Soucheray v. Corps of Engineers of United States Army, 483 F. Supp. 352 (W.D. Wis. 1979); Edison Sault Electric Co. v. United States, 552 F.2d 326 (Gt. Cl. 1977).

213. 320 N.Y.S.2d 405, 66 Misc. 2d 114 (N.Y. City Civ. Ct. 1971).

214. 60 Misc. 2d 538 (N.Y. Fam. Ct. 1969).

215. If not immune, he is necessarily acting outside the scope of his official duties, see, c.g., U.N. CHARTER art. 105, para. 2, and the IGO's core activities could not be involved.

216. Congress prohibited the garnishment of funds owned by a foreign sovereign but held by an IGO. See supra note 74 . Such funds, however, are likely to be used for, and to be necessary to the achievement of, core functions; whereas paying the wages of an employee, here only a private person, see supra note 215 , is merely an administrative matter that can create no additional liability. Moreover, any judgment obtained would be against the employee in his private capacity, and would not affect the IGO's ability to direct or control him.

217. 45 I.L.R. 446 (1972) (summarized supra p. 1182).

218. Unlike Broadbent and Weidner, this was no internal administrative matter; at issue were the rights of someone with no ties to the UN. Cf. supra pp. 1188-90 (IGO has jurisdiction over internal matters; tort, even more than contract, plaintiffs, should have opportunity for legal relief). But allowing suits for such large amounts might well impede the public operations of the United Nations, see Ehrenfeld, supra note 198, at 91-92; supra pp. 1190-91, and probably would tend to repress offers of even partial compensation.

219. "Subjects" includes citizens, as assumed by the 1976 REPORT, supra note 6 , throughout, and permanent residents. See Broadbent, 628 F.2d 27, 28. The term may or may not embrace transient or illegal aliens. 
the jurisdiction of the United States; ${ }^{220}$ under conflict-of-laws principles, the United States thus has some obligation to provide a forum. ${ }^{221}$ But Congress has acted to eliminate the forum formerly provided by the common law; $; 22$ the government of the United States, not general principles of law, denies the "day in court" that is so important to due process. Although this does not necessarily mean the IOIA is unconstitutional, ${ }^{223}$ it does urge that the United States government provide compensation for this deprivation.

Also, Congress may not accept, or the courts may reject, such a restricted jurisdictional immunity. If Congress decided to adopt such an immunity, the process of enacting the necessary legislation might consume many years; ${ }^{224}$ moreover, the courts generally have been unwilling to deal with matters involving foreign affairs, ${ }^{225}$ even when Congress has explicitly conferred such jurisdiction on them. ${ }^{226}$ Retention of absolute immunity under the IOIA would present a stronger case for providing legal redress of some kind.

Since the United States government presumably granted immunity to IGOs on the basis that such immunity gained more for its citizens as a whole than it cost them, ${ }^{227}$ substitution of that government when an IGO defendant is immune is a fair solution. ${ }^{228}$ France, for example, has already employed such a device to protect its nationals in ordinary tort actions. ${ }^{229}$

220. The Uniled States having no jurisdiction over defendant IGOs as such, it can assert jurisdiction only on the basis of a plaintifTs ties to it or of events occurring within its boundaries. See, e.g., Home Ins. Co. v. Dick, 281 U.S. 397, 410 (1930); Lashbrooke, Vertical Integration and Restraints by the Oil-Producing Countries: Antitrust Implications and Supply Considerations, 13 N.Y.U. J. INT'L L. \& POLITIC'S 193, 195-97 (1980). Even the far-reaching "effects" test depends upon the action's having effects within United States territory. See, e.g., United States v. Aluminum Co. of America, 148 F.2d 416, 443-45 (2d Cir. 1945) (L. Hand, J.); RESTATEMENT (SEC.OND) OF THE FOREIGN RELATIONS LAW OF THE UNITED STATES § 18, Reporters' Note 2 (1965).

221. See, e.g., Hughes v. Fetter, 341 U.S. 609,613 (1951) (state must provide forum when, inter alia, parties residents in it); Broderick v. Rosner, 294 U.S. 629, 643 (1935) (same when defendant incorporated in state).

222. IGOs had no immunity in American law before enactment of the IOIA; immunity had in fact been refused on the ground that no statute provided for it. See supra p. 1168. Domestic and foreign sovereigns, on the other hand, derived their immunity from general principles of common law. See The Schooner Exchange, 11 U.S. at 135-36; supra pp. 1168, 1172-73, 1185.

223. As indicated earlier, IGOs are, for example, composed of governments possessing commonlaw immunity.

224. For example, drafting began on the FSIA, enacted in 1976, in the mid-1960's. 1976 REPORT, supra note 6 , at 9 .

225. See supra pp. 1184-85.

226. See, e.g., Note, Garey v. National Oil Co.: The Foreign Sovereign Immunities Act Embargoed, 42 U. PITTS. L. REV. 149 (1980).

227. See supra note 33. Domestic sovereign immunity law now accepts the principle that a single citizen should not bear the cost of an activity that benefits the entire community. E.g., Ayala v. Philadelphia Bd. of Pub. Educ., 453 Pa. 584, 593-94, 305 A.2d 877, 884 (1973).

228. Cf. Note, The Jurisdictional Immunity of Foreign Sovereigns, 63 YALE L.J. 1148, 1167-69,

1171-72 (1954) (proposing such substitution for immune foreign sovereign).

229. See Fortune Insurance Co. v. Etat Francais, 1964 Bulletin des arrets de la Cour de cassation, chambres civiles, section civile 248, 45 I.L.R. 462 (1972); CODE CIVILE art. 1384, s. 1; N.A.T.O. 
Gongress could easily enact appropriate legislation, under a theory of international immunity acceptable to it; or, since the United States is by definition a participant in the entity being sued, the courts could hold it liable under partner or joint venturer theories. ${ }^{230}$

Such a solution would further the interests of private parties dealing with IGOs; if the IGO were immune, the United States government would remain secondarily liable when not itself immune as the domestic sovereign. ${ }^{231}$ The nation's interests would not be materially harmed, for the relevant IGO activities are insignificant compared to those of the United States government itself; and, in any case, Congress has the power to control the extent of domestic sovereign liability. The same reasons make it unlikely that IGOs would suffer through the efforts of the United States to control their activities or unnecessarily to restrict their immunity, ${ }^{232}$ especially since the United States benefits both independently and as a member from the IGO's operations and immunity. ${ }^{233}$

Even when the United States government was immune, plaintiffs' ability to recover by petitioning Congress would be enhanced. Asserting the secondary liability of the United States converts a potentially complex in-

AGREEMENT art. 8, June 19, 1951, 4 U.S.T. 1792, T.I.A.S. No. 2846.

230. IGOs possess juristic personality, and thus are separate from their members. Reparation for Injuries Suffered in the Service of the United Nations, 1949 I.C.J. 173; Seyersted, International Personality of Intergovernmental Organizations, 4 INDIAN J. INT'L L. 1 (1964). The chief reason, however, for limiting the liability of shareholders for corporate debts is to encourage the rapid growth of commercial investment and enterprise by combining unlimited opportunity for profit with limited possible loss. But nations become members of IGOs for public rather than profit-oriented purposes; and, being sovereign states, they are able to specify the extent of their own immunity from suit. Hence, this rationale does not apply.

An IGO could, then, be treated as a partnership, which possesses no juristic personality, e.g., Helvering v. Smith, 90 F.2d 590, 591 (2d Cir. 1937) (L. Hand, J.). Thus, each partner is personally liable for the debts of the partnership. UNIF. PARTNERSHIP ACT $\S 15$ (1914); see also $1 \mathrm{G}$. HORNSTEIN, CORPORATION LAW AND PRACTICE § 3 (1959); D. VAGTS, BASIC CORPORATION LAW 30 (2d ed. 1979).

Alternatively, because of the limited or specific purposes of most IGOs, they could be treated as joint ventures. See N. LATTIN, THE LAW OF CORPORATIONS 10 (2d ed. 1971); see also, e.g., A. BROMBERG, CRANE AND BROMBERG ON PARTNERSHIP 189 (1968). Members of joint ventures are liable as partners. N. LATTIN, supra, at 10-11; A. BROMBERG, supra, at 193; H. HENN, HANDBOOK OF THE LAW OF CORPORATIONS 79 (1970).

Under either theory, then, a member of an IGO may be held secondarily liable for debts of the organization, subject to the provisions of the member's immunity law.

231. The United States government has waived its immunity in many situations. Sce supra p. 1186.

232. Past practice suggests that the United States will use even a right of subrogation only reluctantly. For example, the Overseas Private Investment Corporation (OPIC) had decided not to seck compensation from the Jamaican government, which had allegedly caused the loss for which OPIC was sued as guarantor, before arbitration of a dispute between a private investor and OPIC, even though damages could have run to $\$ 60-80,000,000$. Conversation with E. Donald Elliott, attorney for OPIC in that case, Mar. 17, 1981; see Revere Copper \& Brass v. Overseas Private Investment Corp., O.P.I.C. Case No. 16100137 76, Aug. 24, 1978, affd, Misc. No. 78-0296 (D.D.C. Dec. 8, 1978), affd, 628 F.2d 81 (D.C. Cir. 1980), cert. denied, 446 U.S. 983 (1980).

233. 1945 HOUSE REPORT, supra note 2, at 947 (quoted supra note 33); 1945 SENATE REPORT, supra note 4 , at 2 (same). 
Jurisdictional Immunities

ternational question into a relatively straightforward issue of domestic politics. ${ }^{234}$

Conclusion

This Note has attempted to resolve two questions presented by Broadbent v. $O A S:{ }^{235}$ whether the FSIA is to be read directly into the IOIA; and to what extent IGOs are to be immune under the IOIA from the jurisdiction of United States courts. It has also attempted to provide a means of redress for injured private persons in cases in which an IGO defendant is immune.

The IOIA and the FSIA are independent statutes. Nonetheless, using Broadbent's implicit model of IGOs as government agencies rather than governments led to a theory of restricted IGO immunity. IGOs would be immune with respect to their core activities but no others-a rule to be tested by the functional immunity principle.

That rule leaves IGOs immune in at least some cases. To minimize injury to private persons, the United States government should be substituted as defendant under a partner or joint venturer theory.

234. Cf. supra pp. 1184-85 (discussing political character of international as opposed to domestic suits).

235. 628 F.2d 27 (D.C. Cir. 1980). 